\title{
A nemzeti költségvetési szabályok elterjedése és hatása Európában
}

A nemzeti szintü költségvetési szabályok robbanásszerü európai elterjedése az elmúlt negyedszázadban több okra vezethető vissza. A szabályok bevezetésére, illetve a szabályrendszerek megerősítésére gyakran a költségvetési problémák által kikényszerített költségvetési kiigazítások keretében került sor, ám erősítette ezt a folyamatot az európai integráció is. Azok az országok, amelyek az európai adósságválság során nem szorultak külső segítségre, jellemzően szigorúbb költségvetési szabályrendszert alakítottak ki, ami azt jelezheti, hogy ez az eszköz képes lehet hozzájárulni a költségvetési fenntarthatósághoz. A saját adatbázison elvégzett ökonometriai kutatásunk is azt bizonyítja, hogy a nemzeti költségvetési szabályok konjunktúra időszakában erősítik a költségvetési fegyelmet. Továbbá azt találtuk, hogy a szabályok eredményessége szempontjából fontos az erős jogi háttér, a megfelelően rögzített célrendszer, a riasztási mechanizmus, az ellenőrző testület, valamint a szabályok müködéséröl szóló nyilvános diskurzus. ${ }^{*}$

Journal of Economic Literature (JEL) kód: H60, H62, E62.

Miközben a kilencvenes évek elején csupán néhány európai országban volt nemzeti szintü költségvetési szabály, ${ }^{1}$ addig a 2010-es évekre egész Európában elterjedtek a költségvetési politika számára makrogazdasági korlátot jelentő, legtöbbször valamilyen költségvetési teljesítményre vonatkozó, aggregált index formájában megjelenő elöírások (Kopits-Symansky [1998]). Ez már önmagában is indokolná a témával kapcsolatos ismereteink összegyüjtését és bővítését, ám miközben az egyes (tag-)államok kormányai egymás után szánták rá magukat költségvetési keretrendszerük megerő-

\footnotetext{
* A szerző ezúton fejezi ki köszönetét hasznos tanácsaiért Ádám Jánosnak, Adamecz Annának, Baksay Gergelynek, Balatoni Andrásnak, Benczes Istvánnak, Berta Dávidnak, Csomós Balázsnak, Czeglédi Pálnak, Jankovics Lászlónak, Jenei Tamásnak, Muraközy Lászlónak, Neményi Juditnak, Oblath Gábornak és P. Kiss Gábornak, valamint az anonim lektoroknak. A tanulmányban kifejtett nézetek a szerző véleményét tükrözik, és nem feltétlenül esnek egybe az MNB hivatalos álláspontjával. A hibákért, tévedésekért a felelősség természetesen kizárólag a szerzőt terheli.

${ }^{1}$ A költségvetési szabályok jellemzőiről, típusairól lásd bővebben Hallerberg és szerzőtársai [2001], IMF [2009], Benczes [2011], Tóth [2017], Berta-Tóth [2017].
}

Tóth G. Csaba vezető közgazdasági elemző, Magyar Nemzeti Bank (tothg@mnb.hu).

A kézirat első változata 2017. május 18-án érkezett szerkesztőségünkbe.

DOI: http://dx.doi.org/10.18414/KSZ.2017.11.1119 
sítésére, uniós szinten is elötérbe került a téma. A közösség vezetői a 2007-2008-as világgazdasági válságból kialakult adósságválság egyik okát abban látták, hogy az EU nem volt képes szupranacionális szabályok segítségével fegyelmezett költségvetési politikára kényszeríteni a tagállamok egy részét, ezért újragondolták a közösség eszközrendszerét, ennek részeként pedig a korábbinál jóval nagyobb hangsúlyt kaptak a nemzeti költségvetési szabályok. Mindez tetten érhető a magyar gyakorlaton is. Miközben a válság kitöréséig nem volt egyetlen olyan költségvetési szabály sem, amely a központi költségvetésre vonatkozott, jelenleg már négy különböző előírás szabályozza az állam gazdálkodását. ${ }^{2}$

Gazdaságpolitikai jelentősége mellett a téma azért is aktuális, mert az európai országok költségvetési szabályokkal kapcsolatos, közel negyedszázados tapasztalata már elegendő információval szolgál ahhoz, hogy tudományos módszerekkel (is) górcső alá vegyük az eszköz működését, eredményességét, hatását. Másrészt a 20072008-as válság, illetve az abból kialakult adósságválság a fenntarthatóság szempontjából mérceként is szolgál, lehetőséget teremtve ezzel a szabályokkal kapcsolatos ismereteink és tapasztalataink bővítésére.

Tanulmányunk célja, hogy a szakirodalomra építve bemutassuk, milyen tényezők járultak hozzá a nemzeti költségvetési szabályok elterjedéséhez, különböző módszerek segítségével értékeljük, hogy ezek a szabályok mennyiben képesek erősíteni a költségvetési fenntarthatóságot és a fegyelmet, illetve hogy rámutassunk a szabályok azon jellemzőire, amelyek leginkább képesek hozzájárulni ezekhez a célokhoz.

Ennek megfelelően először igyekszünk összefoglalni a nemzeti költségvetési szabályok elterjedésének egymást követő hullámait, majd megnézzük, hogy az európai adósságválság során milyen különbségek rajzolódtak ki a külső pénzügyi segítségre szoruló és a válságnak ellenálló országok szabályrendszerei között. Ezt követően egy saját kutatás alapján megvizsgáljuk, hogy konjunktúra idején a költségvetési szabályok képesek-e erősíteni a költségvetési fegyelmet, illetve hogy a költségvetési szabályok mely jellemzői járulnak hozzá az eredményességhez.

\section{A költségvetési szabályok elterjedése}

A költségvetési szabályok előfutárai az Egyesült Államokban jelentek meg a 19. század közepén (Kopits [2001]). Ezek elsősorban procedurális szabályok voltak, és az egyes államok eladósodásának megakadályozását célozták. Bevezetésüket nem a washingtoni vezetés tette kötelezővé, hanem a tagállamok maguk döntöttek úgy, hogy beillesztik a jogrendszerükbe. Ehhez szükség volt arra, hogy a szövetségi kormány, amely 1790-től kezdve fél évszázadon át számtalanszor kimentette az eladósodott tagállamokat, 1840-ben visszautasítsa a néhány évvel korábbi pénzügyi, majd az azt követő gazdasági válságban súlyos pénzügyi problémákkal küzdő tagállamok segítségkérését (Henning-Kessler [2012]). A csődhullám, amely ennek nyomán végigsöpört az

\footnotetext{
2 A magyar szabályrendszerről lásd bővebben Kopits-Romhányi [2010], Balatoni-Tóth [2012], Baksay-P. Kiss [2013], Balatoni [2015].
} 
országon, hasznos leckének bizonyult, a következö másfél évtizedben 19 amerikai tagállam alkotta meg a saját költségvetési szabályát azzal a céllal, hogy biztosítsák költségvetésük fenntarthatóságát.

Majdnem egy évszázaddal később, sok tekintetben hasonló körülmények között, született meg az első költségvetési szabály Európában (Luechinger-Schaltegger [2013]). A föderális berendezkedését tekintve az Egyesült Államokhoz közel álló Svájcban a kantonok nagyon jelentős költségvetési autonómiával rendelkeznek évszázadok óta. ${ }^{3}$ A szövetségi állam azonban sem az írott törvények, sem a szokásjog alapján nem tekinti feladatának, hogy megmentse a fizetésképtelenné vált kantonokat, ezért utóbbiak, azzal a céllal, hogy biztosítsák a költségvetési politika fenntarthatóságát - amerikai társaikhoz hasonlóan -, saját maguk döntöttek a bevezetés mellett (Locher és szerzötársai [2015], Kirchgässner [2013]). Az első költségvetési szabály 1929ben St. Gallenben született, és - igaz, több évtizedes lemaradással - később szinte az összes svájci kantonban követték e példát.

A központi költségvetésre is kiterjedő, nemzeti szintű numerikus költségvetési szabályok a kontinensen a második világháború után elszórtan néhány nyugateurópai államban bukkantak fel. Elsőként az 1949-ben megalkotott német ${ }^{4}$ alkotmány rendelkezett az egyenleg lehetséges mértékéről (US GAO [1994], Hamker [2011], World Bank [2008]), később a kontinensen Olaszország és Hollandia is követte a példáját (Berndsen [2001]). Esetükben többnyire azért volt szükség már az államháztartás egészére vonatkozó költségvetési szabályok bevezetésére, hogy biztosítsák a monetáris reformok miatt is szükségessé vált stabilizációs programok sikerét, fenntarthatóságát (Kopits [2001]).

A fenti példák azt jelzik, hogy költségvetési szabályok megjelenése az évezred utolsó évtizedében Európában nem nevezhető előzmény nélkülinek, ám az kijelenthető, hogy a kilencvenes évek elejétöl ebben a tekintetben új korszak kezdődött. ${ }^{5}$ Részben ez magyarázza empirikus elemzésünk időszakának kiválasztását. Ekkortól ugyanis rövid idő alatt ugrásszerủen megnőtt a nemzeti szintű költségvetési szabályok népszerűsége, robbanásszerüen terjedt el az új eszköz az európai országokban (Debrun és szerzőtársai [2008], EC [2009], IMF [2009]). Alig több mint két évtized alatt, 1990 és 2014 között 14-röl 114-re, azaz több mint nyolcszorosára nőtt a kontinensen érvényes, számszerüsített költségvetési szabályok száma. Ráadásul, míg a korszak elején jellemzően csupán néhány országban az alacsonyabb közigazgatási szintek (például helyi önkormányzatok) gazdálkodására vonatkozott elöírás, addig a 2010-es évek elejére szinte az összes uniós tagállamban a költségvetési politika eszköztára kiegészült legalább egy olyan nemzeti költségvetési szabállyal, amelyik a központi kormányzat gazdálkodását is szabályozta. Mindez azt is jelenti, hogy 2015-ben már minden tagállamban volt ilyen elöírás. Országonként

\footnotetext{
${ }^{3}$ A hasonlóság nem véletlen: később nagymintás ökonometriai vizsgálatokkal is kimutatták, hogy a föderális berendezkedésű országok esetében nagyobb az esély költségvetési szabály bevezetésére (Elbadawi és szerzötársai [2015]).

${ }^{4}$ A német költségvetési szabályokról bővebben lásd Benczes-Váradi [2011] munkáját.

${ }^{5}$ Kopits [2001] az Új-Zélandon 1994-ben elfogatott költségvetési felelősségi törvény elfogadását tekinti az új korszak kezdetének.
} 
átlagosan négy szabály volt érvényben, de olyan ország is akadt (Franciaország, Olaszország, Portugália és Bulgária), ahol több mint fél tucat különböző nemzeti költségvetési szabály volt hatályos.

A szabályok növekedése mellett jelentősen erösödött a költségvetési szabályozás intézményi beágyazottsága, erőssége is. Mindez jól érzékelhető az Európai Bizottság költségvetési szabályokat tartalmazó adatbázisából (EC [2015]), amely sok más hasznos információ mellett tartalmaz egy Fiscal Rules Index (FRI) elnevezésü mutatót, amely az egyes országokban az adott évben érvényes költségvetési szabályok együttese által alkotott szabályrendszer erősségét, intézményi beágyazottságát méri. Az FRI - mint általában minden más olyan index, amely egy intézményrendszer minőségét próbálja megragadni - messze nem tökéletes, ám a kvantitatív kutatások szempontjából kulcsfontosságú.

A mutató értékét a szabályrendszert alkotó egyes szabályok erősségét mérő Fiscal Rule Strengten Indexek (FRSI) együttes értéke határozza meg. Ez utóbbi mutató a szabály által lefedett közpénzügyi terület nagysága mellett a következő nyolc alindex értékét összegzi: 1 . a szabály jogi alapja, 2. a célok rögzítettsége, 3. ellenőrző testület, ${ }^{6}$ 4. riasztási mechanizmus, 5. szankcionáló testület, 6 . korrekciós mechanizmus, 7. mentesítő záradék, 8. nyilvánosság. ${ }^{7}$ A mutató tehát nem azt méri, hogy mit mond a szabály, illetve hogy a költségvetési politika megfelel-e az előírásainak (erről lásd bővebben Reuter [2015]), hanem hogy a szabályozáshoz kapcsolódó szervezeti, jogi és intézményi háttér milyen mértékben támogatja a szabály működését. ${ }^{8}$

A szabályrendszerek erősségét mérő átlagos $F R I$ a szabályok számához hasonlóan a kilencvenes évek elejétől - eltekintve egyetlen évtől (1996) - egyenletesen emelkedett (1. ábra). A válság kitörése után ez a folyamat megtört, néhány évvel később azonban ugrásszerủ növekedés következett mind a szabályok számában, mind pedig az FRI alakulásában. Mindez azt jelenti, hogy a kilencvenes évek elejétől nem csupán a szabályok terjedtek el Európában, de az új szabályok működését jellemzően egyre erősebb intézményi környezet is segítette.

A költségvetési szabályok robbanásszerủ elterjedésének megértéséhez érdemes két másik mutatón keresztül is megvizsgálni a folyamatot. Ha a szabályok helyett a szabályt alkalmazó országok számát, illetve a szabályok közpénzügyi lefedettségét ${ }^{9}$ vonjuk górcső alá, és külön vizsgáljuk a régi EU15 tagországokat, illetve az újonnan

\footnotetext{
${ }^{6}$ A költségvetési tanácsokról lásd bővebben Calmfors-Wren-Lewis [2011], Beetsma-Debrun [2016], illetve Jankovics [2012].

${ }^{7}$ A pontos kérdéseket és válaszokat lásd a Függelék F1. táblázatában.

${ }^{8} \mathrm{Az}$ FRI mutató országonként és évenként összegzi az FRSI mutatókat oly módon, hogy az aggregálás utolsó lépésében a teljes, tehát a legelső évtől a legutolsó évig terjedő adatbázist egy 0 átlagú, 1 standard hibájú eloszlássá alakítják át. Ez azt jelenti, hogy évente nemcsak a friss adatokkal bővül az adatbázis, hanem frissül is minden adat. A minimumérték (ami azt az esetet jelzi, amikor egy országban az adott évben nincs költségvetési szabály általában) -1 körül ingadozik, a mutató legmagasabb értéke pedig 2 és 4 között alakul. A saját kutatáshoz a 2013-as évvel végződő adatbázist használtuk, a szabályok elterjedéséről szóló fejezet azonban a legfrissebb, 2015-tel záruló adatbázisra épül (EC [2015]).

${ }^{9}$ A szabályok közpénzügyi lefedettsége azt mutatja meg, hogy az állam pénzügyeinek hány százalékára terjed ki az adott szabály. Ily módon mérhetővé válik a különbség például a kormányzati szektor egészére, illetve az önkormányzatokra vonatkozó előírások között.
} 
1. ábra

Az FRI és a költségvetési számok szabályának alakulása

FRI

A szabályok száma

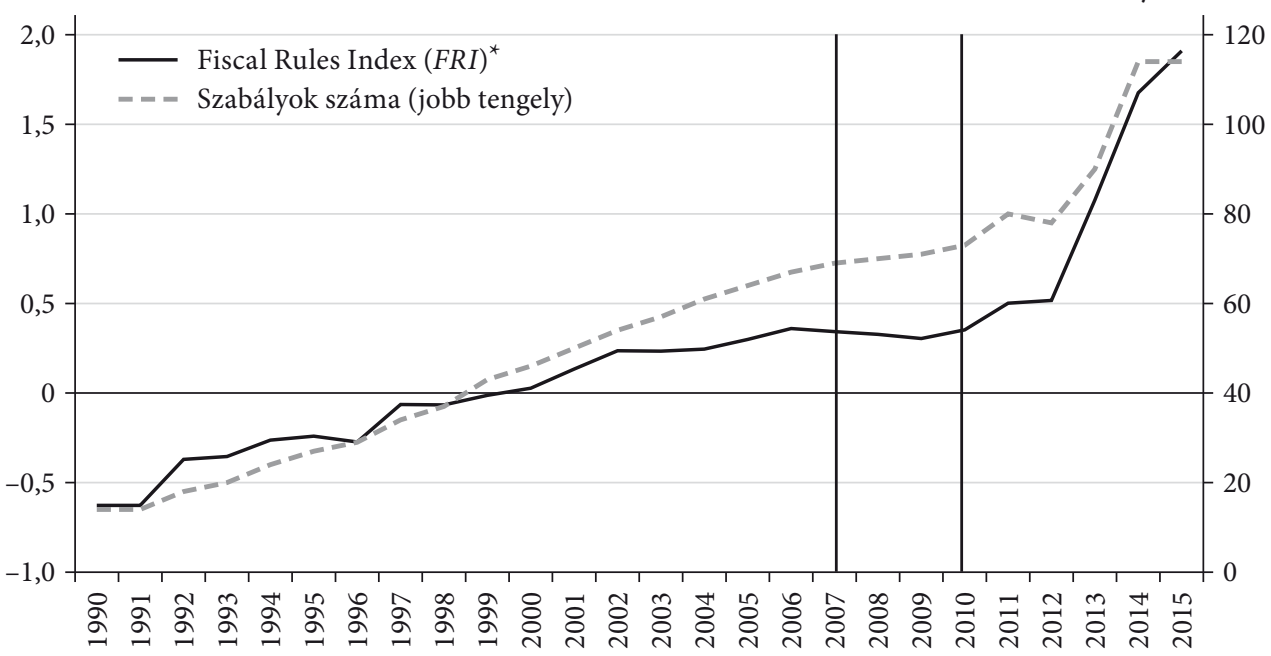

Megjegyzés: az FRI esetében csak azokat az országokat vettük figyelembe, ahol volt költségvetési szabály.

Forrás: saját számítás az Európai Bizottság adatbázisa alapján.

\section{2. ábra}

A szabállyal rendelkező országok száma és a közpénzügyi lefedettség

Országok száma

Közpénzügyi lefedettség

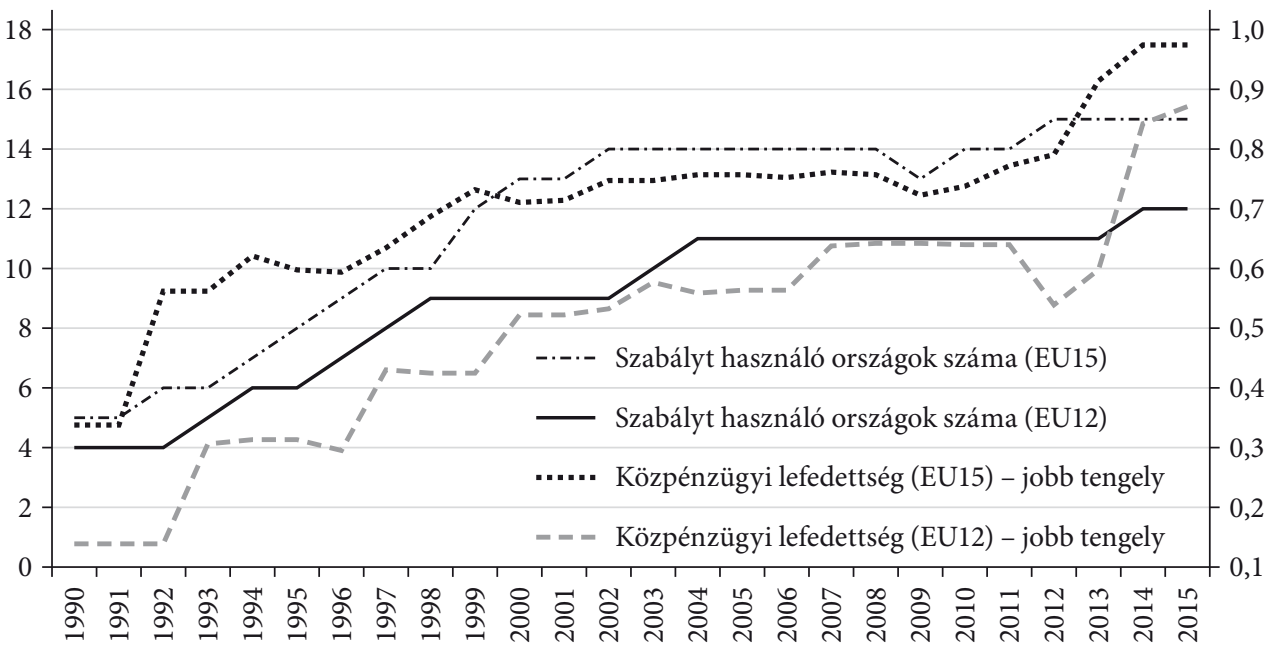

Megjegyzés: a közpénzügyi lefedettséget úgy mértük, hogy előbb országonként, majd évenként átlagoltuk a különböző szabálytípusok (adósság, egyenleg stb.) közül azokat, amelyek a közpénzügyi területek legnagyobb részét lefedték.

Forrás: saját számítás az Európai Bizottság adatbázisa alapján. 
csatlakozott államokat, akkor a mögöttes folyamatokra utaló szakaszhatárok a két országcsoport esetében látványosabban kirajzolódnak (2. ábra).

Az első fejlemény, amely előidézője volt a kilencvenes évek elejétől a nemzeti szintü költségvetési szabályok európai elterjedésének, a költségvetéssel kapcsolatos fenntarthatósági problémák kialakulása volt. Ez Nyugat-Európa esetében a hetvenes évektől a kilencvenes évek közepéig tartó eladósodásra vezethető vissza, amely részben az olajárrobbanással, részben strukturális problémákkal, részben pedig a jóléti állam megingásával magyarázható (OECD [1991], Corsetti-Roubini [1991], Hallett és szerzőtársai [2003], Muraközy [2012]). A költségvetési egyensúly megbomlása vezetett oda, hogy a 20. század utolsó évtizedében az EU15 tagállamainak körében összesen 29 költségvetési kiigazításra került sor. ${ }^{10}$ A volt szocialista országok esetében a költségvetéssel kapcsolatos problémák, valamint az ebből fakadó kiigazítási igény mögött a legtöbb esetben nem a korábbi évek eladósodása állt, hanem a transzformációs válság és az államháztartási egyenlegek ebből fakadó radikális romlása (Csaba [1994], [2002], Kornai [2005], Roafés szerzőtársai [2014]). Az említett költségvetési problémáknak pedig azért volt jelentős a szerepe, mert a költségvetési szabályok bevezetésére, a szabályrendszerek megerősítésére sok esetben egy költségvetési konszolidáció keretében került sor.

Költségvetési kiigazításra azonban már korábban is bőven volt példa, így ez önmagában nem magyarázná a költségvetési szabályok elterjedését. Ezt igazolja az is, hogy az EU27 tagállamaiban 1995 és 2014 között 43 olyan epizód volt, amikor egy ország az egyik évről a másikra jelentősen erősítette az érvényben lévő nemzeti költségvetési szabályok rendszerét, és ebből 22 alkalom esett egybe költségvetési kiigazítással, azaz az esetek felében kapcsolható konszolidációhoz a szabályrendszerek erősödése. Ez utóbbihoz jelentős mértékben hozzájárult az európai integráció is. A régi tagországok esetében a közös valuta bevezetése, illetve a stabilitási és növekedési egyezmény egyaránt komoly kötelezettséget jelentett a költségvetési politikára vonatkozóan, az új tagországok esetében pedig hasonlóképpen erős fegyelmező szerepe volt az Európai Unióhoz való csatlakozásnak. ${ }^{11}$ Ezt igazolja a 2. ábrán látható eltérés a két országcsoport között: míg az EU15 esetében az intenzív bővülés, legyen szó akár a szabályt használó országok számáról, akár a szabályok közpénzügyi lefedettségéről, körülbelül 2001-2002-ig, azaz az euró készpénzként történő megjelenéséig tartott, ez a töréspont az új tagországok esetében néhány évvel később, körülbelül akkor következett be, amikor a tíz új tagállam csatlakozott a közösséghez.

A kilencvenes évek elején felerősödött (költségvetési) fenntarthatósági problémák, illetve az uniós integráció után a harmadik fontos történelmi tapasztalat, amely hozzájárult a költségvetési szabályok elterjedéséhez, a 2007-2008-as világgazdasági válságból kialakult európai adósságválság volt. Ez egyrészt sok országban egyszerre

${ }^{10}$ Akkor tekintetünk egy időszakot költségvetési kiigazításnak, ha a ciklikusan kiigazított elsődleges egyenleg egyik évről a másikra GDP-arányosan 1,5 százalékot javult.

${ }^{11}$ Közvetetten segítette a költségvetési szabályok elterjedését a volt szocialista országokban a rendszerváltás után lezajlott demokratizálódás is, amelyet részben az uniós csatlakozáshoz kapcsolódó követelmények dinamizáltak. 
jelentett újabb kiigazítási igényt, ${ }^{12}$ amely ismét együtt járt sok esetben szabályok bevezetésével vagy a szabályrendszer megerősítésével. Másrészt az Európai Unió vezetői a 2007-2008-as világgazdasági válságból kialakult adósságválság egyik okát abban látták, hogy a közösség nem volt képes szupranacionális szabályok segítségével fegyelmezett költségvetési politikára kényszeríteni a tagállamok egy részét, ezért újragondolták a közösség eszközrendszerét (lásd Benczes [2013], [2014]). Ennek részeként növelték a szabályok számát, igyekeztek megerősíteni a szabályokat támogató intézményrendszert, valamint elöírták a tagállamok számára a szupranacionális szabályok nemzeti jogrendszerbe való átültetését. Mindez azt jelzi, hogy a tapasztalatok alapján a szupranacionális szabályok nem helyettesítői a nemzeti szintű szabályoknak, sokkal inkább dinamizálják az utóbbiak elterjedését.

\section{Költségvetési szabályok és a fenntarthatóság}

A 2007-2008-ban kitört pénzügyi, majd az abból kinövő reálgazdasági válság számos európai országban adósságválságot okozott. Ennek hatására több mint fél tucat állam szembesült azzal, hogy nem képes pénzügyi igényeit - az addig megszokott módon - a piacról kielégíteni, így kénytelen volt segítséget kérni különböző nemzetközi szervezetektől. Egy állam számára az ilyen helyzetek általában súlyos következményekkel járnak: reálgazdasági visszaeséssel, kényszerü megszorító intézkedések bevezetésével, elszegényedéssel, társadalmi konfliktusokkal és egyéb költségekkel (Reinhart-Rogoff [2009], Vidovics-Dancs [2014]). A tudomány számára ugyanakkor tanulási lehetőséget is jelentenek annak érdekében, hogy az idevezető társadalmi és gazdasági folyamatok megértésével növeljék az esélyét a hasonló események megelőzésének. Esetünkben a válság elemzése lehetőséget teremt, hogy megvizsgáljuk, létezik-e bármilyen kapcsolat a költségvetési szabályok használata és a költségvetési fenntarthatóság között, azaz arra keressük a választ, hogy a költségvetési szabályok szempontjából felfedezhető-e különbség a költségvetési szempontból fenntarthatatlannak, illetve a fenntarthatónak bizonyult országok gyakorlata között.

A költségvetési fenntarthatóság tágabb értelmezése ugyan a költségvetési korlát fogalmához kötődik, ám az általunk használt szűkebb meghatározás a fizetőképesség fogalmához kapcsolódik. Ez utóbbi a kormány azon képességét jelenti, hogy mindig eleget tud tenni az aktuális törlesztési kötelezettségeknek (Burnside [2005]), erre épülve pedig viszonylagos szakmai konszenzus övezi azt a definíciót, hogy egy költségvetési politika akkor fenntartható, ha az a jövőben sem veszélyezteti az ország fizetőképességét (Croce-Juan-Ramon [2003]).

Természetesen egy állam jövőbeli fizetőképességéről sohasem tudunk biztos ítéletet mondani, nem véletlen, hogy a költségvetési politika ex ante mérésével kapcsolatban rendkívül izgalmas szakmai vita alakult ki, és ez a diskurzus a válság után különösen intenzívvé vált (Baldacci és szerzőtársai [2011], Cottarelli [2011], Afonso-Jalles [2012],

\footnotetext{
${ }^{12}$ Lásd Alesina és szerzőtársai [2015], Darvas-Tschekassin [2015], IMF [2012].
} 
Mahmood-Rauf [2012], Cottarelli-Escolano [2014], De Cos és szerzőtársai [2014]). Tanulmányunkban azonban a témával kapcsolatos kutatások többségével szemben nem a költségvetési fenntarthatóság ex ante megítélésével foglalkozunk, ${ }^{13}$ hanem az ex post mérésre helyezzük a hangsúlyt. Ennek érdekében a fizetőképesség fogalmára építve azt állítjuk, hogy egy adott ország esetében utólag akkor tekinthető a költségvetési politika fenntarthatónak, ha az adott állam a fizetőképességének megörzése érdekében nem szorult nemzetközi szervezetek segítségére. ${ }^{14}$

Ennek megfelelően a vizsgált országokat, az Európai Unióhoz a válság előtt csatlakozott 27 tagállamot két csoportra bontjuk. Fenntarthatatlannak akkor minősítünk egy államot, ha a válságot követően külső segítségre szorult, azaz igénybe vette az IMF készenléti hitelmegállapodás (Stand-By Arrangements) programját (Románia, Magyarország, Lettország) vagy az IMF kiterjesztett hitelmegállapodás (Extended Fund Facility) programját (Portugália, Írország, Ciprus, Görögország) (IMF [2016]). Mellettük azokat az uniós tagállamokat (Olaszország és Spanyolország) soroltuk ide, amelyeknek az államkötvényeiből az ECB még a 2015-ös általános kötvényvásárlási programjának bejelentése előtt egyéni elbírálás alapján vásárolt.

Mivel ebben a fejezetben arra keressük a választ, hogy megfigyelhetö-e olyan közös jellemvonás (együttmozgás) a később fenntarthatatlan költségvetési politikájúnak bizonyult országok között, amelyben eltértek a többi országtól, és amely ily módon hozzájárulhatott ahhoz, hogy külső segítségre szoruljanak, ezért csupán a válság kitörésének időpontjáig vizsgáljuk az adatokat. A 3. ábrán a számok azt jelzik, hogy az egy országra jutó szabályok számában viszonylag kicsi az eltérés a két csoport között: a válság előtti néhány évben mind a fenntarthatók, mind a fenntarthatatlanok körében 2 és 3 között alakult a mutató. Ez azt mutatja, hogy a szabályok jelenléte önmagában nem befolyásolta érdemben a költségvetési politika minőségét.

Amiben jelentős különbség mutatkozott, az a költségvetési szabályrendszer erössége (FRI). A kilencvenes évek elején a mutató értéke még mindkét csoportban igen alacsony volt, ám a fenntartható államok esetében emelkedni kezdett, míg a fenntarthatatlanok esetében alig változott, különösen a kétezres évek első feléig. Ennek eredményeképpen az utóbb fenntarthatónak bizonyult országokban sokkal erősebb intézményi környezetben működtek a költségvetési szabályok, mint azokban az államokban, amelyek később külső segítségre szorultak. Miután láttuk, hogy a szabályok számában nincsen jelentős eltérés, így a két csoport átlagos FRI-je közötti különbség két dologra vezethető vissza: vagy az egyes szabályok erősségét mérő FRSI-re, vagy a szabályok által lefedett közpénzügyi területek nagyságára.

Esetünkben a különbség nagyobbik felét az magyarázza, hogy míg a kétezres évektöl a fenntarthatónak bizonyult országokban a legnagyobb közpénzügyi

${ }^{13}$ Azt érdemes hangsúlyozni, hogy a költségvetés fenntarthatóságát a jövőbeli költségvetési politika határozza meg, ezért a fenntarthatóság a szó szoros értelmében nem mérhető (Pápa-Valentinyi [2008]). Másként fogalmazva, a költségvetési politika mindig fenntartható, csupán az a kérdés, hogy az ehhez szükséges kiigazítást maguk végzik el a tagállamok, vagy pedig a finanszírozási környezet közvetlenül kényszeríti-e ki.

${ }^{14}$ Itt természetesen csak az olyan pénzügyi segítségnyújtást tudjuk figyelembe venni, amelyre sor került az adósságválság kitörését követő öt éven belül. 
3. ábra

Az egy országra jutó szabályok száma és az FRI alakulása

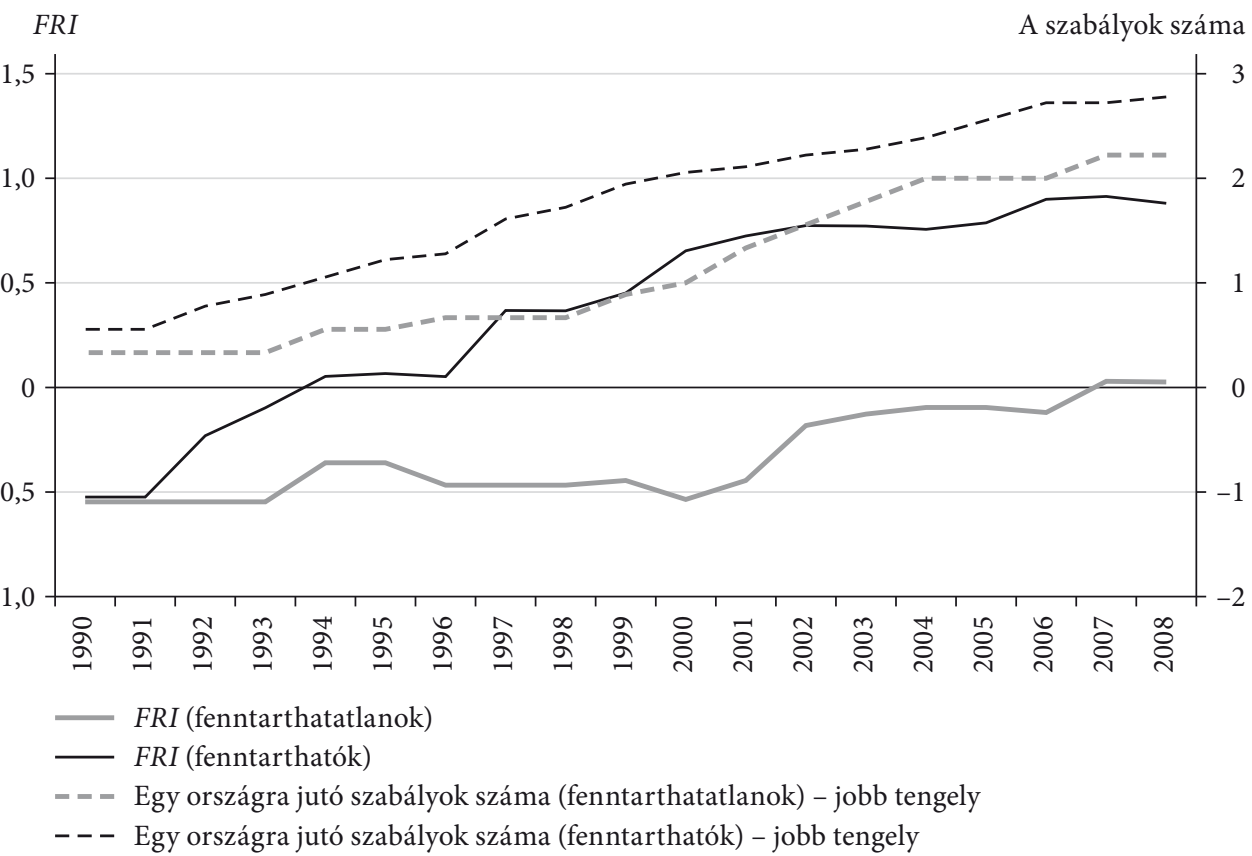

Forrás: saját számítás az Európai Bizottság adatbázisa alapján.

lefedettségű szabályok átlagosan kiterjedtek az állami pénzügyek több mint 70 százalékára, addig a nemzetközi szervezetek segítségére szorult államok esetében a mutató sokáig a 40 százalékot sem haladta meg. Kisebb, de nem elhanyagolható az eltérés a szabályok erősségében (FRSI): e mutató a vizsgált időszak túlnyomó többségében a fenntartható államok esetében 6,5 körül, míg a fenntarthatatlanok esetében 6 körül ingadozott (4. ábra).

Éppen ez utóbbi eltérés miatt megvizsgáltuk azt is, hogy különböző tényezők alindexeit képezve ( $A 1$ : jogi háttér; $A 2$ : célok rögzítése; $A 3$ : ellenőrző testület; $A 4$ : riasztási mechanizmus; $A 5$ : szankcionáló testület; $A 6$ : korrekciós mechanizmus, $A 7$ : mentesítő záradék, $A 8$ : nyilvánosság) melyik két csoport között találunk érdemi eltérést. Az 5. ábrán az egyes alindexeket a teljes időszakra átlagoltuk. A vizsgált változók közül érdemben magasabb pontszámot kaptak a fenntartható országok az A2, A3, $A 4$ és $A 8$ dimenziójában. Jobban szerepeltek az utóbb fenntarthatatlannak bizonyult országok a jogi háttér $(A 1)$ és a korrekciós mechanizmus (A6) tekintetében, ${ }^{15}$ míg a szankcionáló testületek függetlensége (A5) szempontjából nem volt érdemi különbség.

${ }^{15}$ A jogi háttér ( $\left.A 1\right)$ esetében ez feltehetően azzal magyarázható, hogy a jellemzően fenntartható költségvetési politikát folytató skandináv országokban bevezetett szabályok egy része viszonylag gyenge jogi alapokra támaszkodott, sokszor csupán koalíciós megállapodásra vagy politikai nyilatkozatra épült. 
4. ábra

A közpénzügyi lefedettség és a szabályok száma

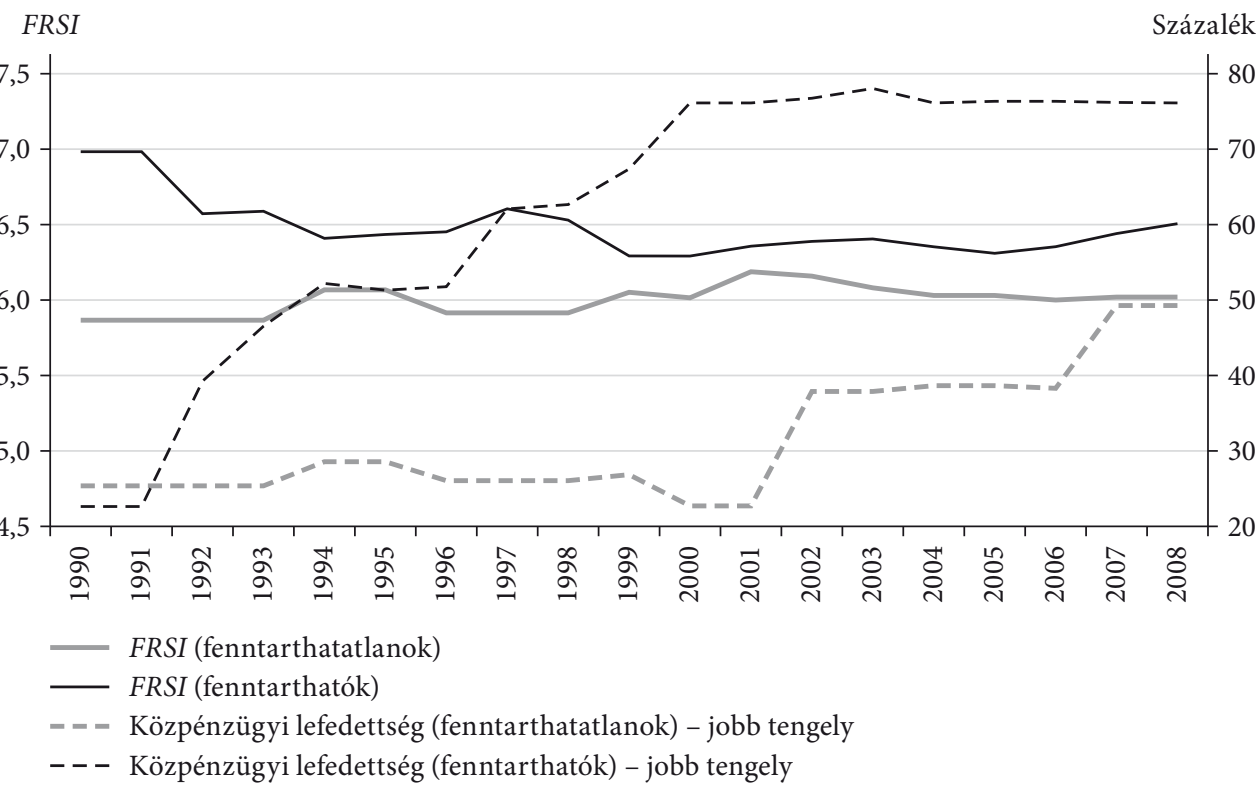

Forrás: saját számítás az Európai Bizottság adatbázisa alapján.

\section{5. ábra}

Az FRSI-t alkotó alindexek átlagos értéke (1990-2008)

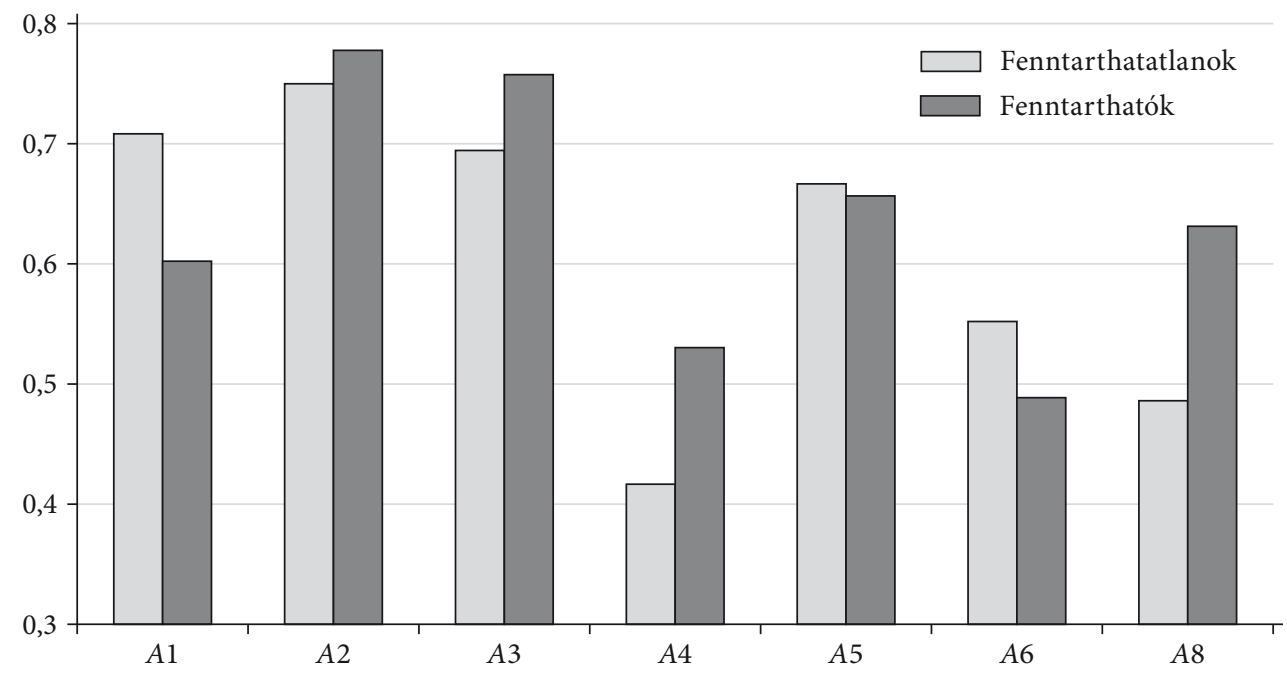

Rövidítések: A1: jogi háttér; $A 2$ : célok rögzítése; $A 3$ : ellenőrző testület; $A 4$ : riasztási mechanizmus; $A 5$ : szankcionáló testület; $A 6$ : korrekciós mechanizmus; $A 8$ : nyilvánosság.

Megjegyzés: az A7 jelü mentesítő záradékot azért hagytuk ki az összehasonlításból, mert az többnyire az adósságtípusú szabályokhoz kapcsolódik, a többi szabály esetében kevésbé értelmezhető. Forrás: saját számítás az Európai Bizottság adatbázisa alapján. 
Összevetve a válság előtti költségvetési szabályokat és szabályrendszereket a válságban pénzügyi segítségre szorult, illetve fenntarthatónak bizonyult országokban, a következő kép rajzolódik ki. A szabályok számában nincs jelentős különbség a két csoportban, a szabályrendszerek viszont sokkal erősebbek voltak a jól teljesítő államokban. Ez elsősorban azzal magyarázható, hogy az utóbbiak körében a szabályok az államháztartás sokkal nagyobb területét fedték le, de az is hozzájárult, hogy az egyes szabályok intézményi környezete erősebb volt. A fenntarthatónak bizonyult országokban konkrétabbak voltak a szabályban szereplő célok, nagyobb szerep jutott a független ellenőrző testületeknek, volt riasztási mechanizmus, és a költségvetési szabállyal, illetve annak betartásával kapcsolatos viták nagyobb teret kaptak a médiában, illetve a nyilvánosságban.

\section{A költségvetési szabályok hatása}

Az előző fejezetben bemutatott leíró statisztika abba az irányba mutat, hogy létezik együttmozgás a költségvetési szabályrendszerek erőssége és a költségvetési politika fenntarthatósága között. Ebben a fejezetben az oksági kapcsolat irányát igyekszünk ökonometriai módszerekkel megvizsgálni a kutatási kérdés leszűkítésével és pontosabb definiálásával. A szabályok és a költségvetési politika közötti kapcsolat irányának és nagyságának pontosabb méréséhez és megértéséhez érdemes KennedyRobbins [2001] kategorizálását követve megkülönböztetnünk négy csatornát, amelyen keresztül a szabályok kifejthetik a hatásukat.

Az első - a továbbiakban általunk vizsgált - a fegyelmezett költségvetési politika erősítése. A szabályok ugyanis képesek lehetnek arra ösztönözni a döntéshozókat, hogy konjunktúra esetén fegyelmezett gazdaságpolitikát folytassanak annak érdekében, hogy válságban elegendő költségvetési mozgásterük legyen az állami keresletélénkítéshez (fegyelmezö csatorna). A költségvetési szabályok úgy is hozzájárulhatnak a fenntarthatósághoz, hogy növelik az ország hitelességét, javítják a befektetők megítélését, ami könnyebb és olcsóbb forrásbevonást jelent az adott ország számára (hozamcsatorna). Ezenkívül a szabályoknak jelentős szerepük lehet a különböző közigazgatási szinteken (például önkormányzatoknál) zajló gazdálkodás megfelelö összehangolásában (föderatív csatorna), valamint akkor is segíthetnek a költségvetési szabályok, ha képesek olyan szemléletmódot beemelni a költségvetési tervezés gyakorlatába, amely nem csupán az adott évi, aktuális kiadásokat veszi figyelembe, hanem a később felmerülő (egészségügyi, demográfiai stb.) problémákat, költségeket is (tervezési csatorna).

A továbbiakban a felsorolt négy csatorna közül a fegyelmező csatornát vonjuk górcső alá, összhangban azzal, hogy az FRI-t tartalmazó adatbázist felhasználó ökonometriai kutatások legnagyobb csoportja is azt vizsgálja, hogy a nemzeti költségvetési szabályok mennyiben képesek hozzájárulni a költségvetési egyenleg javulásához. A korábbi kutatások eredményei közötti eltérések háttere részben technikai jellegü (például a vizsgált országok és évek száma, a választott becslési eljárás típusa, a költségvetési teljesítményt mérő mutató kiválasztása, illetve a szabályok mellett figyelembe vett egyéb tényezők, 
kontrollváltozók jellege és mennyisége). A tartalmi kérdés, amely az eredmények értelmezése szempontjából is kulcsfontosságú, az endogenitás kezelése (Poterba [1996]). Ez utóbbi több forrásból táplálkozik, és visszatérő problémája minden ökonometriai és nem ökonometriai vizsgálatnak e témában. Ha kimutatható, hogy a költségvetési szabályok megjelenése és erősödése együtt jár a költségvetési fegyelem javulásával, az nem jelenti feltétlenül, hogy a kettő közötti kapcsolat egyirányú, és csupán az előbbi befolyásolja az utóbbit. Nagyon sok logikus magyarázat szól amellett, hogy az oksági kapcsolat fordított irányú is lehet, ilyenkor az amúgy is fegyelmezett költségvetési politikát folytató politikusok a szabályok bevezetésével akarják akár a választók, akár más gazdasági vagy politikai szereplők, közösségek számára jelezni elkötelezettségüket a takarékos állami gazdálkodás mellett.

A vizsgálatok egy része nem foglalkozott az endogenitás problémájával (EC [2006], Marneffe és szerzőtársai [2010], Bergman és szerzőtársai [2014], Nerlich-Reuter [2013]); sokan instrumentális változókkal kezelték (Debrun és szerzötársai [2008], Ayuso-iCasals és szerzőtársai [2009], Afonso-Hauptmeier [2009], Dahan-Strawczynski [2010]); a legújabb kutatások pedig innovatív módon igyekeztek megkerülni a problémát (Heinemann-Yeter [2014], Sacchi-Salotti [2015]). Közös azonban az empirikus vizsgálatokban, hogy mind szoros kapcsolatot talált a költségvetési szabályok megjelenése és erőssége, illetve a különböző egyenlegmutatók javulása között (Heinemann és szerzötársai [2016]), és bár szerepel az összes tanulmányban hangsúlyozottan az, hogy az oksági kapcsolat irányának meghatározása problémás, a különböző módon végrehajtott vizsgálatok mind abba az irányba mutatnak, hogy a szabályok feltehetően képesek javítani a költségvetési fegyelmet.

\section{A kutatás módszertana}

Az említett tanulmányokhoz hasonlóan a költségvetési szabályok hatását első lépésben mi is oly módon igyekszünk megvizsgálni, hogy a szabályok erősségét mérő $F R I$ mutatót beépítjük egy költségvetési reakciófüggvénybe (Bohn [1998]). Vizsgálatunk időhorizontja a válság előtti közel másfél évtizedet (1995-2008) foglalja magában. A periódus kezdeti időpontjának kiválasztásában kiemelt szerepet játszott az adatok összehasonlíthatóságának biztosítása, a végpontot pedig a válság kitörése határozta meg. Az ily módon összeállított, éves gyakoriságú adatbázis 14 évre vonatkozóan tartalmazza a válság előtt az Európai Unióhoz csatlakozott 27 tagállam adatait. Az adatok nagy része az Európai Bizottság AMECO adatbázisából származik, a költségvetési szabályok, illetve szabályrendszerek forrása szintén az Európai Bizottság korábban már bemutatott adatbázisa.

A szakirodalmi gyakorlathoz képest kutatásunk három szempontból jelent újdonságot. Az egyik változtatás, hogy a kormányzat költségvetési irányultságát a GDParányos elsődleges egyenleggel mérjük ${ }^{16}$ a szakirodalomban gyakrabban használt

\footnotetext{
${ }^{16}$ Hozzánk hasonlóan az elsődleges egyenleget használta Marneffe és szerzőtársai [2010], AfonsoHauptmeier [2009], valamint Cordes és szerzőtársai [2015].
} 
ciklikusan kiigazított elsődleges egyenleg helyett, ${ }^{17}$ mivel véleményünk szerint az előbbi éppen az anticiklikus politika definíciója miatt megfelelőbb mutató erre a célra. A szakemberek széles körében elterjedt nézet szerint ugyanis az anticiklikus politika feltétele az adóráták és diszkrecionális kiadások GDP-arányos nagyságának változatlansága (lásd Alesina és szerzőtársai [2008]). Konjunktúra idején ugyanis a kiadási oldalon a nem diszkrecionális tételek (például a munkanélküli-járandóságok) csökkentik az összes kiadás GDP-arányos nagyságát, míg a bevételi oldalon a progresszív adók javítják az egyenleget. Ezek az automatikus stabilizátorok, amelyek közvetlen állami beavatkozás nélkül, önmagukban képesek mérsékelni a gazdasági ciklus ingadozásait (Tóth [2010]). Mivel jellegénél fogva a ciklikusan kiigazított mutatók éppen ezeket a hatásokat szürik ki, ezért célszerü az anticiklikus politika méréséhez az elsődleges egyenlegmutatót használni.

Választásunk indoklása jól érzékelhető a következő gyakorlati példán keresztül is. Egy lejtőn lefelé guruló autó megállításában szerepet játszhat a motorfék (automatikus stabilizátorok) és a soför fékezése (diszkrecionális intézkedések) is. A soför célja, hogy megállítsa az autót, és hogy ennek érdekében úgy fékezzen, hogy figyelembe veszi a motorfék hatását is. A soför tehát közvetlenül csupán a saját fékezését tudja befolyásolni, de amikor azt vizsgáljuk, hogy elérte-e a célját, akkor nem azt nézzük, hogy mennyit fékezett, hanem hogy a két különböző fékezési mechanizmus együttes hatásának eredményeképpen megállt-e az autó. A fentieken túl az elsődleges egyenleg mint célváltozó használata azért is alkalmasabb, mert a ciklikusan kiigazított mutatóval ellentétben ez független a csupán jelentős bizonytalansággal becsülhető potenciális kibocsátástól (Darvas-Kostyleva [2011], Mellár [2016]), és így az utólagos revíziók kevésbé változtatják meg az adatsorokat (Checherita-Westphal-Ždarek [2015]). ${ }^{18}$

Az endogenitás problémáját a korábbi módszerektől eltérően úgy próbáltuk meg kezelni, hogy igyekeztünk elkülöníteni egymástól azt a politikai akaratot, amelyből a fegyelmezett költségvetési politika fakad, attól a politikai akarattól, amelyik a költségvetési szabály bevezetéséért felelös. Ezt úgy tettük meg, hogy különválasztottuk (később kiszűrtük) azokat az eseteket, amikor egy kormány úgy irányítja az országot, hogy a saját maga által alkotott költségvetési szabályrendszer van érvényben, és azokat a megfigyeléseket, amikor a regnáló kormánynak valamelyik korábbi kormány által létrehozott szabályrendszer elöírásait, korlátjait kell figyelembe vennie.

Ennek érdekében létrehoztunk egy új változót $(G O V)$, amely az alábbi kategorizálás szerint három értéket vehet fel az adatbázisban szereplő megfigyelések esetében:

- a vizsgált periódusban (évben) költségvetési szabály nélkül müködő államok;

- olyan államok, amelyek a vizsgált periódusban (évben) saját szabállyal müködtek; akkor tekintjük egy kormány sajátjának a szabályt, ha annak megalkotásakor, illetve elfogadásakor az éppen regnáló kormányfö (prezidenciális rendszerekben az elnök) vagy annak egyik párttársa volt a miniszterelnök;

\footnotetext{
${ }^{17}$ Eredményeink megerősítése érdekében azonban a regressziós becslést elvégeztük a ciklikusan kiigazított elsődleges egyenlegre is (lásd Függelék F3. táblázat).

${ }^{18}$ Annak érdekében, hogy eredményeink robusztusságát igazoljuk, illetve hogy becsléseink összehasonlíthatók legyenek a korábbi kutatásokkal, a legfőbb számításokat elvégezzük a ciklikusan kiigazított egyenlegre is.
} 
- olyan államok, amelyekben a vizsgált periódusban örökölt szabály volt érvényben. Idetartozik minden olyan megfigyelés, amelyik kimarad az előző kettőből. Ez azt jelenti, hogy azok az országok, illetve évek kerültek ebbe a csoportba, ahol van érvényes költségvetési szabály, de annak létrehozása, megalkotása nem köthető a regnáló miniszterelnökhöz vagy annak pártjához.

A szétválasztás azért tűnik célravezetőnek, mert az utóbbi esetben biztosan állíthatjuk, hogy a szabályt létrehozó politikai akarat (egy korábbi kormányé) elkülönül attól a politikai akarattól (a regnáló kormányétól), amelyik a költségvetési politikáért felel, így a korábban említett endogenitási probléma kezelhető. Bár a felosztás reményeink szerint logikus és célravezető, a csoportosítás során a következetes elhatárolás érdekében szükség volt néhány további feltétel pontos meghatározására.

A kategorizálás legnehezebb része annak megállapítása volt, hogy éppen melyik kormány volt hatalmon az adott költségvetési szabály elfogadásakor. Ehhez ugyanis tudni kell, hogy ez utóbbit pontosan mikor fogadták el. A kiinduló feltételezésünk az volt, hogy a szabályokat az életbelépés előtti évben fogadták el. Ott, ahol ez a kategorizálás szempontjából döntő volt, vagy nem volt egyértelmű, például azért, mert a szabály életbelépését megelőző évben több kormány is működött, további kutatásokat végeztünk annak érdekében, hogy megerősítsük vagy éppen megcáfoljuk, korrigáljuk a kiinduló feltételezéseinket. Ennek részeként több ország esetében is felvettük a kapcsolatot helyi intézményekkel (például költségvetési tanácsokkal), illetve kutatókkal, szakemberekkel. ${ }^{19}$

A vizsgált periódusban többször elöfordult, hogy egy évben több olyan költségvetési szabály is érvényben volt, amelyek különböző kormány alatt születtek. Ilyenkor a kategorizálás szempontjából azt a szabályt tekintettük irányadónak, amelyik az állami pénzügyek nagyobb területét fedte le. Abban az esetben, ha a két szabály által lefedett állami pénzügyek nagysága nem tért el 5 százalékpontnál nagyobb mértékben, ott azt a szabályt vettük figyelembe, amelyiknek nagyobb volt az FRSI-értéke. Kormányváltások évében attól függően döntöttünk, hogy az adott évi költségvetési politika melyik kormány viselkedését tükrözi, hogy év közben mikor lépett hivatalba az új kormány. Ha az első félévben, akkor az adott évi költségvetés már az új kormány felelőssége, és az ő teljesítményét méri, ha csak a második félévben, akkor pedig a leköszönő kormányét.

Bár az új változó bevezetésével véleményünk szerint kezelhető az endogenitás problémája, fel kell hívnunk a figyelmet, hogy az elméleti keretrendszer koherenciájának biztosítása érdekében még egy feltételezéssel kellett élnünk. A problémát az okozza, hogy ha egy kormány különösebb következmények és külső kényszerek nélkül dönthetne arról, hogy életben tart-e egy szabályt, vagy pedig eltörli, akkor (ismét) nem tudnánk elkülöníteni egymástól azt a politikai akaratot, amely életben tartja a szabályt, attól, amelyik a költségvetési politikáért felel. A gyakorlatban azonban feltételezésünk szerint ez nem így van, és ez több dologgal is alátámasztható.

${ }^{19}$ Ausztria, Bulgária, Észtország, Lettország és Portugália esetében sikerült a helyi költségvetési tanács vagy központi bank egyik munkatársa, vezetője, illetve a témával foglalkozó helyi közgazdász segítségével megválaszolni a vitás kérdéseket. 
Egyrészt a költségvetési szabályokkal kapcsolatos elöírások és kötelezettségek egy része a legmagasabb szintű jogforrásban, alkotmányban vagy alaptörvényben szerepel. Ilyen esetekben az új kormánynak sokszor nincs meg a szükséges parlamenti többsége, hogy megváltoztassa vagy eltörölje a szabályt. Másrészt egy költségvetési szabály eltörlése is költségekkel jár (Debrun-Kumar [2007]), hiszen jelentösen csökkenti a kormány hitelességét, elbizonytalaníthatja a befektetőket azzal kapcsolatban, hogy vajon elkötelezett-e az adott állam a fegyelmezett költségvetési politika mellett.

Feltételezésünket az adatok is megerősítik. Miközben a teljes időszakban összesen 95 szabály müködött, és 47 olyan kormányváltásra került sor, amikor volt hatályos költségvetési szabály az adott államban, csupán öt országban fordult elö, hogy egy új kormány a hivatalba lépése évében eltörölt egy költségvetési szabályt, és nem volt olyan eset, amikor egy új kormány úgy módosított volna egy érvényes szabályt, hogy annak erőssége (FRSI-értéke) megváltozott volna. Ráadásul a kormányváltás után azonnal eltörölt szabályok jellemzően nem tartoztak azok közé, amelyek az adott időszakban az állami pénzügyek legnagyobb részét lefedték, így nem befolyásolták, hogy az adott megfigyelés a saját szabályú vagy az örökölt szabályú csoportba kerül. Mindezek miatt azt gondoljuk, hogy az örökölt szabályok csoportjára lehet úgy tekinteni, mint ahol a szabály létrehozása elkülönült a regnáló kormány akaratától.

A harmadik változtatás a szakirodalom többségére jellemző gyakorlathoz képest nem közvetlenül az adatbázist érinti, hanem a kérdésfeltevést. Az eddig publikált kutatások túlnyomó többségében a szerzők a gazdasági ciklustól függetlenül keresték az összefüggést a költségvetési szabályok és a költségvetési egyenleg között. Ezek mögött az a kiinduló feltételezés azonosítható, hogy a költségvetési szabályok akkor eredményesek, ha javítják a költségvetési gazdálkodást, vagyis annál jobb, annál eredményesebb egy költségvetési szabály, minél inkább képes javítani az adott ország államháztartási egyenlegét. Ez azonban véleményünk szerint nem pontos, hiszen a költségvetési szigor nem minden időszakban és minden körülménytől független célja a költségvetési politikának, ezen belül pedig a költségvetési szabályoknak. Ami a költségvetési politika, azaz bővebben az állam feladatai (Musgrave [1959]) és a költségvetési szabályok céljai között egyaránt megjelenik (Kennedy-Robbins [2001]), az a makrogazdasági stabilitás biztosítása. A költségvetési politika ugyanis a költségvetési irányultság szempontjából akkor megfelelö, ha válság (például kereslethiányos időszak) esetén képes élénkíteni a gazdaságot, a gazdaság prosperálása esetén pedig szigorú és fegyelmezett.

Ezért a költségvetési szabályoknak nem az a céljuk, hogy a gazdasági ciklustól függetlenül szigorú költségvetésre kényszerítsék az országokat, hanem hogy akkor tegyék ezt, amikor prosperál a gazdaság, válság esetén pedig ne akadályozzák a költségvetési lazítást. ${ }^{20}$ Mindezek miatt mi a továbbiakban nem általánosságban vizsgáljuk a költségvetési szabályok és az egyenleg közötti kapcsolatot, hanem kizárólag konjunktúra idején, amikor valóban elvárható a fegyelmezett költségvetési politika.

\footnotetext{
${ }^{20}$ Válság esetén természetesen a lazítás mértékét is határok között kell tartani, ám egyelőre nincs arra recept, hogy pontosan hol van ez a határ, ami megnehezíti, hogy ebből a szempontból vizsgáljuk egy költségvetési szabály hatékonyságát.
} 


\section{Adatok és becslési eredmények}

A költségvetési szabályrendszerek erősségét mérő $F R I$ értéke a vizsgált időszakban $-1,01$ és $+2,13$ között szóródott. Előbbi érték jelezte, ha egy országban nincs érvényben lévő nemzeti szintü költségvetési szabály. A 27 tagország közül három olyan állam volt (Ciprus, Görögország és Málta), ahol 1995 és 2008 között egyetlen évben sem volt érvényes költségvetési szabály, ezekben az országokban a mutató értéke folyamatosan -1,01 volt. A többi tagország esetében viszont döntően erősödtek a költségvetési szabályok (6. ábra).

6. ábra

Az FRI értéke a vizsgált országokban, 1995 és 2008

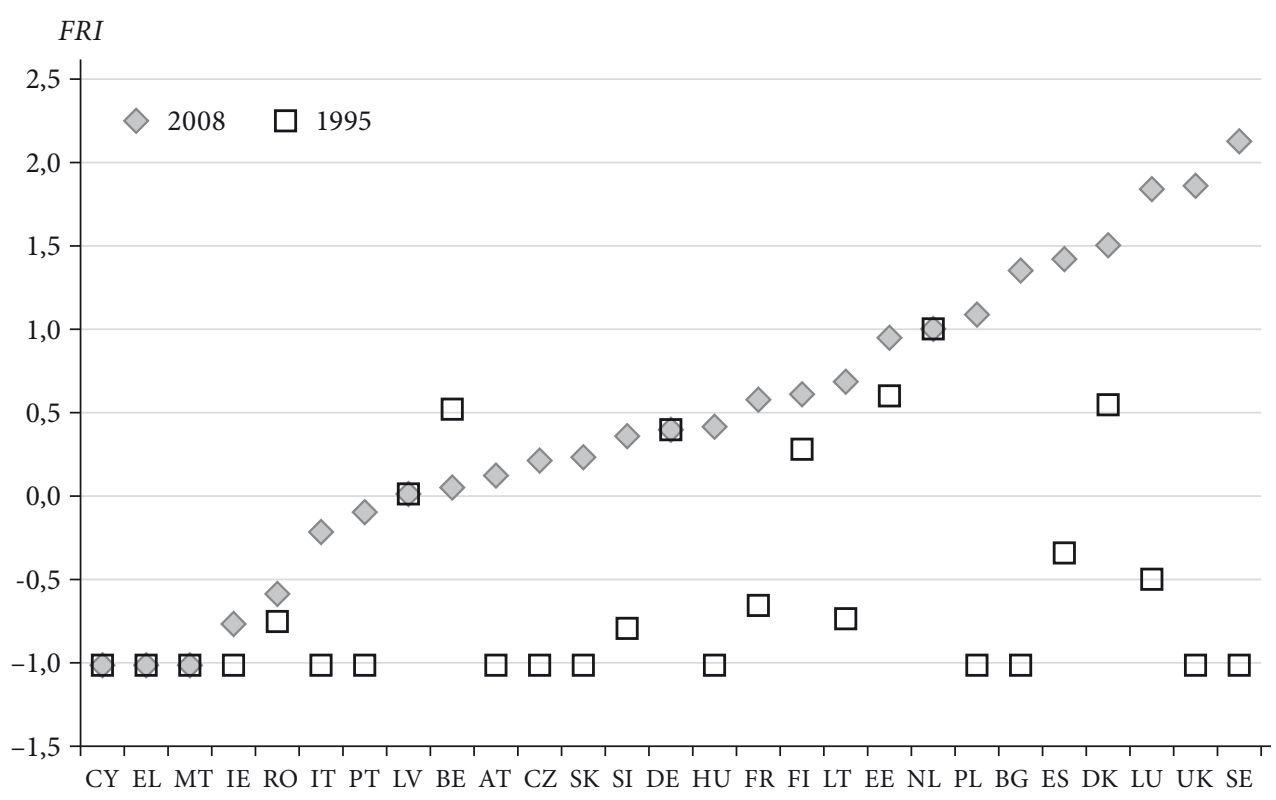

Országröviditések: CY: Ciprus, EL: Görögország, MT: Málta, IE: Írország, RO: Románia, IT: Olaszország, PT: Portugália, LV: Lettország, BE: Belgium, AT: Ausztria, CZ: Csehország, SK: Szlovákia, SI: Szlovénia, DE: Németország, HU: Magyarország, FR: Franciaország, FI: Finnország, LT: Litvánia, EE: Észtország, NL: Hollandia, PL: Lengyelország, BG: Bulgária, ES: Spanyolország, DK: Dánia, LU: Luxemburg, UK: Egyesült Királyság, SE: Svédország. Forrás: Fiscal rules database (EC [2015]).

A vizsgált időszak elején Hollandia, Észtország, Dánia, Belgium és Németország állt az élen, míg 2008-ban az öt legerösebb szabályrendszer sorrendben Svédországban, az Egyesült Királyságban, Luxemburgban, Dániában és Spanyolországban volt érvényben. Összességében, míg 1995-ben az átlagos FRI-0,54 volt a teljes adatbázisban, addig 2008-ra a mutató 0,45-ra emelkedett, az időszak egészének az átlaga pedig 0,03 volt. Az átlagos elsődleges egyenleg GDP-arányos nagyságát tekintve változékonyabb a kép. Az időszak első felében folyamatosan javult a mutató egészen az 
ezredfordulóig, ami részben azzal magyarázható, hogy az euró bevezetése komoly ösztönzőként hatott az érintett országok kormányaira, senki nem akart a rossz költségvetési mutatók miatt kimaradni ez euróövezet létrehozásából. Ezt követően azonban jelentősen romlott az átlagos elsődleges egyenleg, ami egyrészt a Nyugat-Európát is érintő 2002-2003-as gazdasági válsággal, másrészt pedig azzal magyarázható, hogy a közös valuta bevezetése után eltűnt az a kényszer, amely fegyelmezett költségvetési politikára kényszerítette (volna) a régi tagállamok többségét.

Mielőtt rátérünk az ökonometriai eljárások eredményeinek bemutatására, fontos hangsúlyozni, hogy számításaink egy sor olyan feltételezést tartalmaznak, amelyről nincsenek pontos ismereteink. Ezek közé tartozik, hogy a becslések során a lineáris kapcsolatok létét vizsgáltuk, miközben feltételezhetjük, hogy a költségvetési szabályok marginális hatása nem független a szabályozás szintjétől. Hasonlóképpen nem tudtuk figyelembe venni azt, amire már több más kutatás is felhívta a figyelmet (például Heinemann és szerzőtársai [2013]), hogy a szabályok hatása függhet más tényezőktől, például a politikai kultúrától, a tágabb intézményrendszer struktúrájától vagy éppen az állampolgárok egy-egy meghatározó attitüdjétől.

A teljes adatbázisban szereplő, összesen 378 megfigyelés közül 290-ben volt érvényben valamilyen nemzeti szintü költségvetési szabály, 88 esetben pedig egyáltalán nem. $\mathrm{Az}$ endogenitás kezelésében kulcsszerepe van az általunk létrehozott új változónak $(G O V)$, amellyel a szabály nélkül müködő, a saját szabállyal müködő és az örökölt szabállyal működő megfigyeléseket különítettük el. A felosztás eredményeképpen az összes megfigyelés közül 133 eset került a saját szabályok csoportjába, 157 az örökölt szabályok csoportjába, és maradt 88 eset, amikor nem volt érvényben lévő szabály (Függelék F1. ábra). A regressziós vizsgálat során csupán az örökölt szabállyal müködő és a szabály nélküli megfigyeléseket vettük figyelembe, és ezek közül is kiszürtük azt a hat országot, ahol a vizsgált időszak alatt egyszer sem változott az FRI értéke.

A ciklikus pozíció megragadása érdekében létrehoztunk egy GAP3 elnevezésű kétértékü változót, amely az 1 értéket veszi fel akkor, amikor a potenciális GDP arányában mért kibocsátási rés nagyobb, mint $+0,5$, minden más esetben 0 . A továbbiakban az általunk vizsgált magyarázó változó ( $F R I)$ és a GAP3 interakcióját vizsgáljuk, amely jellegénél fogva azt mutatja meg, hogy konjunktúra esetén (amikor a kibocsátási rés nagyobb, mint 0,5) mennyiben járul hozzá az FRI az elsődleges egyenleghez. A küszöbérték azért 0,5 , és nem 0 , mert a mutató becslése, különösen az előrejelzése rendkívül bizonytalan, márpedig egy kormánynak biztosnak kell lennie abban, hogy vége van a válságnak, amikor a keresletszükítő költségvetési politikáról dönt. Fontos azonban hangsúlyoznunk, hogy a kapott eredmények nem változnak akkor sem, ha 0 a küszöbérték, ami jelzi a megállapításaink robusztusságát. Ezeket a számításokat a Függelék F2. táblázatában közöljük.

A regressziós becsléshez az általános momentumok módszerének (GMM) egy speciális változatát használjuk, amelynek kialakítása az Arellano-Bond [1991] szerzőpáros nevéhez füződik. Ez a dinamikus modell instrumentális változók segítségével a magyarázó változók változása alapján becsüli meg a függő változó változását. Instrumentális változókként a függő változó és a magyarázó változók késleltetett értékeit használjuk. Ennek a módszernek a legnagyobb előnye az OLS-sel szemben, hogy a 
függő változó késleltetett értéke is szerepelhet a magyarázó változók között, márpedig ez a költségvetési reakciófüggvények esetében jelentősen növeli a modell magyarázó értékét (Balázsi és szerzőtársai [2014], Nickell [1981]).

A regressziós egyenlet bal oldalán az eddig tárgyaltaknak megfelelően a GDP-arányos elsődleges egyenleg áll, a jobb oldalon szerepeltetjük a függő változó késleltetett értékét, a szabályok erősségét mérő $F R I$-t, a kibocsátási rés bináris változóját (GAP3), a kettő szorzatát, valamint a szakirodalmi gyakorlatnak megfelelően a Világbank által a kormányzati hatékonyság mérésére kidolgozott indexet (WGI), az egy före jutó bruttó hazai termék vásárlóerő-paritáson számolt értékét $(G D P)$, valamint az adósságráta $(d)$ késleltetett értékét. Ezen túlmenően bekerült a magyarázó változók közé a politikai ciklusok hatását kiszürni hivatott $E L C T$, amely azt méri, hogy a tárgyévhez képest hány év múlva lesz a következő országgyülési választás, illetve az EURO nevű változó, amely azt a kapcsolatot igyekszik megragadni, hogy az eurót készpénz formájában 2001-ben bevezető országok körében a bevezetés előtt fontos követelmény volt a fegyelmezett költségvetési politika. Így ez egy kétértékủ változó, amely a vizsgált időszak kezdetétől 2000 -ig az 1-es értéket veszi fel az érintett 12 ország esetében. Az ezt követő időszakokban, illetve a többi ország esetében a mutató értéke 0 .

$$
\begin{aligned}
& p b_{i, t}=\beta_{1} p b_{i, t-1}+\beta_{2} F R I_{i, t}+\beta_{3} G A P 3_{i, t} \times F R I_{i, t}+\beta_{4} G A P 3_{i, t}+\beta_{5} W_{i, t}+ \\
& +\beta_{6} d_{i, t-1}+\beta_{7} E L C T_{i, t}+\beta_{8} G D P_{i, t}+\beta_{9} E U R O_{i, t}+c .
\end{aligned}
$$

A modellbecslés legfontosabb eredménye számunkra az, hogy az interakciós változó szignifikánsan hat a költségvetési fegyelemre (1. táblázat). Ez azt jelenti, hogy válság esetén nincs bizonyítható hatása a költségvetési szabályoknak az egyenlegre, viszont konjunktúra idején, ha az FRI értéke 1-gyel megemelkedik, akkor a GDP-arányos elsődleges egyenleg 1,03 százalékponttal javul. ${ }^{21}$ Ezenkívül az elsődleges egyenleg késleltetett értéke és a kormányzati hatékonyságot mérő WGI esetében tekinthető bizonyítottnak az oksági viszony. Esetünkben a Wald-próba 0,00-os értéke szintén megerősíti a kapott eredményt. ${ }^{22}$

Összességében tehát, ha az adatbázisból a saját szabályú országokat kiszürve kezeljük az endogenitás problémáját, és csak arra koncentrálunk, hogy konjunktúra esetén hogyan müködnek a költségvetési szabályok, akkor azt kapjuk, hogy azok képesek érdemben hozzájárulni a fegyelmezett költségvetési politikához, javítani az államháztartás egyenlegét. Mivel legjobb tudomásunk szerint ilyen módon más még nem próbálta kezelni az endogenitást, mint ahogy olyan kutatást sem találtunk, ahol elkülönítve, ezzel a módszerrel csupán konjunktúra esetén vizsgálják a szabályokat, így számításainkat nem tudjuk közvetlenül összevetni másokéval.

Becslésünket részben emiatt elvégeztük úgy is, hogy a függő változót kicseréltük a szakirodalomban gyakrabban használt ciklikusan kiigazított egyenlegre, és azt találtuk, hogy a költségvetési szabályrendszer erősségét mérő FRI mutató növekedése

${ }^{21} \mathrm{Az}$ FRI és az interakció koefficiensének összege nem volt szignifikáns.

${ }^{22}$ A multikollinearitás miatt a regressziós becslést úgy is elvégeztük, hogy a magyarázó változók közül kihagytuk az FRI-t és a GAP3-at, ám az interakciójuk ebben az esetben is szignifikánsnak bizonyult, a paraméter értéke pedig 0,97 volt. 
1. táblázat

$\mathrm{Az}$ Arellano-Bond-becslés eredményei

\begin{tabular}{lc}
\hline Magyarázó változók & Függő változó $(p b)$ \\
\hline Elsődleges egyenleg $(p b[-1])$ & $0,16^{* *}$ \\
& $(0,02)$ \\
Fiscal Rules Index $(F R I)$ & $-0,30$ \\
FRI × GAP3 & $(0,60)$ \\
& $1,03^{* * *}$ \\
Kibocsátási rés $(G A P 3)$ & $(0,00)$ \\
& 0,25 \\
Kormányzati hatékonyság $(W G I)$ & $(0,27)$ \\
& $1,86^{*}$ \\
Adósságráta, késleltetéssel $(d[-1])$ & $(0,09)$ \\
& 0,04 \\
Választási ciklus $(E L C T)$ & $(0,16)$ \\
& 0,11 \\
Bruttó hazai termék $(G D P)$ & $(0,22)$ \\
Euró bevezetése $(E U R O)$ & $-0,02$ \\
$N$ & $(0,94)$ \\
& 0,41 \\
\end{tabular}

Megjegyzés: zárójelben a $p$ valószínűségi értékek szerepelnek. Az Arellano-Bond-becslést klaszterezett standard hibákkal végeztük el ország és idő fix hatás mellett.

${ }^{\star * *} 1$ százalékos szinten, ${ }^{\star *} 5$ százalékos szinten, ${ }^{\star} 10$ százalékos szinten szignifikáns értékek.

konjunktúra esetén szignifikánsan javítja ezt a mutatót is. ${ }^{23}$ Ez illeszkedik Bergman és szerzőtársai [2014] eredményeihez, amely szintén az Arellano-Bond-modell segítségével vizsgálta meg az FRI és a különbözö költségvetési mutatók kapcsolatát az EU-s tagállamok 22 évnyi (1990-2011) adatát tartalmazó adatbázison. Becslésük szerint, ha az FRI 1-gyel emelkedik, akkor a GDP-arányos ciklikusan kiigazított költségvetési egyenleg 0,47 százalékponttal javul.

Teljesen más módszerrel jutott hozzánk hasonló eredményre Heinemann-Yeter [2014], valamint Sacchi-Salotti [2015] is, akik szintén azt találták, hogy a költségvetési szabályok képesek erősíteni a fegyelmezett költségvetési politikát. A fentieken túl közvetve megerősíti eredményeinket Bergman és szerzőtársainak egy korábbi munkája is (Bergman és szerzötársai [2013]), amelyben az endogenitást ugyan nem kezelték a szerzők, ám szintén az Arellano-Bond-módszerrel vizsgálták az adatbázisukat képező teljes idősor (1990-2012) mellett külön a gazdasági válság éveit (20092012) is. Azt találták, hogy a teljes adatbázisban az FRI 1-gyel való növelése 0,54

\footnotetext{
${ }^{23}$ Az interakció együtthatója 0,96 volt, és szignifikánsnak bizonyult. A részletes eredményeket lásd
} a Függelék F3. táblázatában. 
százalékponttal javítja a GDP-arányos, ciklikusan kiigazított egyenleget, míg a válság éveire szükített modell esetében az FRI értéke negatív volt, és nem volt szignifikáns. E két információból együttesen látható, hogy a költségvetési szabályok válságmentes években biztosan érdemi hatást tudtak gyakorolni a költségvetési fegyelemre. Bár a válságos és válságmentes évek ily módon történő felosztása nem felel meg pontosan a kibocsátási rés nagyságához igazított, általunk használt kategorizálásnak, valamint az endogén változó sem teljesen ugyanaz, úgy véljük, Bergman és szerzőtársainak eredményei is megerősítik a megállapításainkat.

Miután bebizonyítottuk, hogy konjunktúra esetén a költségvetési szabályok erősítése képes javítani a költségvetési fegyelmet, megvizsgáljuk, hogy ebből a szempontból a költségvetési szabályok mely jellemzői a legfontosabbak. Ehhez az FRSI alindexeire vonatkozó változók segítségével arra a kérdésre keressük a választ, hogy a költségvetési szabályok mely tulajdonságai segítik leginkább a fegyelmezett költségvetési politikát, illetve hogy a különbözö dimenziók szerint végrehajtott egy-egy változtatás mennyiben módosítja a költségvetési szabályok hatékonyságát. Míg azonban az eddig használt adatbázisban szereplö összes többi változóra igaz, hogy egy év és egy ország esetében egy értéket vesz fel, addig az egyes tulajdonságok, alindexek egy-egy szabályra vonatkoznak, ezért ez utóbbiakat minden ország esetében évente összesítettük. Ezt követően a változókra külön-külön, egyesével elvégeztük az Arellano-Bond-féle regressziós becslést, amelyet az (1) egyenlethez analóg módon írtuk fel, azzal a különbséggel, hogy az $A_{j}$ változó a különböző tulajdonságokra kapott pontszámokat jelöli.

$$
\begin{aligned}
& p b_{i, t}=\beta_{1} p b_{i, t-1}+\beta_{2} A_{j, i, t}+\beta_{3} G A P 3_{i, t} \times A_{j, i, t}+\beta_{4} G A P 3_{i, t}+\beta_{5} W G I_{i, t}+ \\
& +\beta_{6} d_{i, t-1}+\beta_{7} E L C T_{i, t}+\beta_{8} G D P_{i, t}+\beta_{9} E U R O_{i, t}+c .
\end{aligned}
$$

\section{2. táblázat}

A részletes becslések során kapott alindex-együtthatók

\begin{tabular}{lcccccccc}
\hline & $A 1$ & $A 2$ & $A 3$ & $A 4$ & $A 5$ & $A 6$ & $A 7$ & $A 8$ \\
\hline$A_{i}$ & $-1,26^{\star *}$ & $-0,47$ & $-0,60$ & $-0,09$ & $-0,44$ & $-0,07$ & $-0,03$ & $-0,57^{*}$ \\
& $(0,02)$ & $(0,13)$ & $(0,24)$ & $(0,42)$ & $(0,26)$ & $(0,79)$ & $(0,98)$ & $(0,06)$ \\
$A_{i} \times G A P 3$ & $1,06^{\star * *}$ & $0,74^{* * *}$ & $1,05^{\star * *}$ & $1,11^{\star * *}$ & $0,76^{\star *}$ & 0,03 & 0,77 & $0,45^{*}$ \\
$N$ & $(0,00)$ & $(0,00)$ & $(0,00)$ & $(0,00)$ & $(0,03)$ & $(0,88)$ & $(0,35)$ & $(0,09)$ \\
$N$ & 123 & 123 & 123 & 98 & 117 & 82 & 53 & 93 \\
Wald-próba & 0,00 & 0,01 & 0,00 & 0,00 & 0,07 & 0,96 & 0,35 & 0,02 \\
\hline
\end{tabular}

Rövidítések: $A 1$ : törvényi háttér; $A 2$ : célok rögzítése; $A 3$ : ellenőrző testület; $A 4$ : riasztási mechanizmus; $A 5$ : szankcionáló testület; A6: korrekciós mechanizmus; $A 7$ : mentesítő záradék; A8: nyilvánosság.

Megjegyzés: az Arellano-Bond-becslést klaszterezett standard hibákkal végeztük el ország és idő fix hatás mellett.

${ }^{* * *} 1$ százalékos szinten, ${ }^{* *} 5$ százalékos szinten, ${ }^{*} 10$ százalékos szinten szignifikáns értékek. 
A 2. táblázatban csak a számunkra fontos együtthatókat, illetve a Wald-próba eredményeit tüntettük fel. Ahhoz, hogy bármelyik alindexről elmondhassuk, hogy annak növekedése érdemben javítja konjunktúra időszakában az elsődleges egyenleget, szükséges, hogy az $A_{i} \times G A P 3$ együtthatója 0 -tól különböző és szignifikáns legyen, illetve a Wald- próba eredményének kisebbnek kell lennie, mint 0,05. Mindezek alapján az eredményeink azt jelzik, hogy öt olyan jellemző van, amelynek javításával érdemben növelhető a költségvetési szabályok költségvetési fegyelemre gyakorolt pozitív hatása: a jogi háttér, a célok rögzítése, az ellenőrző testület, a riasztási mechanizmus és a nyilvánosság. A többi szempont esetében vagy nem találtunk szignifikáns kapcsolatot, vagy pedig a Wald-próba haladta meg a küszöbértéket.

\section{Összegzés}

Tanulmányunk első részében megvizsgáltuk, hogy milyen tényezőkre vezethető vissza a nemzeti szintü költségvetési szabályok elmúlt negyedszázadban tapasztalt látványos elterjedése, és megállapítottuk, hogy a költségvetési problémák által kikényszerített kiigazítások mellett a fegyelmezett költségvetési politikára vonatkozó uniós elvárások egyaránt dinamizálták ezt a folyamatot. Ez azt is jelenti, hogy a tapasztalatok alapján Európában a szupranacionális szabályok nem helyettesítik a nemzeti szintű szabályokat, sokkal inkább ösztönzik az utóbbiak megjelenését. Ezt követően összegyüjtöttük az európai adósságválság során külső segítségre szorult, ezért a költségvetési politikájuk szempontjából fenntarthatatlannak bizonyult államok, illetve a válságban is stabil gazdálkodással jellemezhető országok költségvetési szabályrendszerei közötti különbségeket. Az egy országra jutó szabályok számában viszonylag kicsi az eltérés a két országcsoport között, viszont a szabályok és a szabályrendszerek egyaránt erősebbek, és a közpénzügyek nagyobb területét fedték le a fenntarthatónak bizonyult államok esetében. Utóbbiak körében a költségvetési szabályokhoz kapcsolódó célokat pontosabban definiálták, rögzítették, gyakrabban létezett a szabály megsértését időben jelző riasztási mechanizmus, többször támogatta a szabály müködését költségvetési tanács, valamint nagyobb nyilvánosságot kapott a szabály müködése.

Saját kutatásunkban azt bizonyítottuk be, hogy a nemzeti szintű költségvetési szabályok képesek konjunktúra idején erősíteni a költségvetési fegyelmet és ezen keresztül hozzájárulni a költségvetési fenntarthatósághoz. Állításunk tudományos újdonsága egyrészt, hogy nem általában, hanem kifejezetten konjunktúra idején vizsgáltuk a költségvetési fegyelmet, másrészt pedig, hogy az endogenitás problémáját úgy kezeltük, hogy csak azokat az eseteket vizsgáltuk, amikor olyan szabály müködött, amelynek létrehozása nem volt köthető az éppen regnáló kormányhoz. Azt találtuk, hogy pozitív kibocsátási rés mellett minél erösebb egy költségvetési szabályrendszer (FRI), annál kedvezőbb a GDP-arányos elsődleges egyenleg. A szabályok egyes jellemzőin belül bizonyítottan erősíti a költségvetési fegyelmet az erős jogi háttér, a megfelelően rögzített célrendszer, ha létezik riasztási mechanizmus, és müködik egy ellenőrzö testület, valamint a szabályok működéséről szóló nyilvános diskurzus. 


\section{Hivatkozások}

Afonso, A.-Hauptmeier, S. [2009]: Fiscal behavior in the European Union: Rules, fiscal decentralization and government indebtedness. ECB Working Paper, No. 1054.

Afonso, A.-JALles, J. T. [2012]: Revisiting fiscal sustainability: Panel cointegration and structural breaks in OECD countries. European Central Bank, Working Paper Series, 1465. https://doi.org/10.2139/ssrn.2180575.

Alesina, A.-Campante, F. R.-Tabellini, G. [2008]: Why is fiscal policy often procyclical? Journal of the European Economic Association, Vol. 6. No. 5. 1006-1036. o. https://doi. org/10.1162/JEEA.2008.6.5.1006.

Alesina, A.-Favero, C.-Giavazzi, F. [2015]: The output effect of fiscal consolidation plans. Journal of International Economics, Vol. 96. Suppl. 1. 19-42. o. https://doi.org/10.1016/j. jinteco.2014.11.003.

Arellano, M.-Bond, S. [1991]: Some Tests of Specification for Panel Data: Monte Carlo Evidence and an Application to Employment Equations. The Review of Economic Studies, Vol. 58. No. 2. 277-297. o. https://doi.org/10.2307/2297968.

Ayuso-I-Casals, J.-Hernández, D. G.-Moulin, L.-Turrini, A. [2009]: Beyond the SGP: Features and effects of EU national-level fiscal rules. Megjelent: Policy Instruments for Sound Fiscal Policies. Palgrave Macmillan, UK, 204-240. o. https://doi.org/10.1057/9780230271791_10.

Baksay Gergely-P. Kiss Gábor [2013]: Second Act - second thoughts: The Hungarian debt rule. MNB Bulletin, Vol. 8. No. 3. 7-13. o.

Balatoni András [2015]: A simple fiscal rule for Hungary. Acta Oeconomica, Vol. 65. No. 1. 149-59. o. https://doi.org/10.1556/032.65.2015.s1.9.

Balatoni András-Tóth G. Csaba [2012]: Az új magyar adósságszabály értékelése. Közgazdasági Szemle, 59. évf. 10. sz. 1107-1137. o.

BALÁzsi LÁszló-Divényi JánOs-KÉZDi GÁboR- MÁTyÁs LÁszló [2014]: A közgazdasági adatforradalom és a panelökonometria. Közgazdasági Szemle, 61. évf. 11. sz. 1319-1340. o.

Baldacci, E.-McHugh, J.-Petrova, I. [2011]: Measuring Fiscal Vulnerability and Fiscal Stress: A Proposed Set of Indicators. IMF Working Paper, No. 94. https://doi. org/10.5089/9781455253333.001.

Beetsma, R.-Debrun, X. [2016]: Fiscal Councils: Rationale and Effectiveness. IMF Working Paper, No. 86. https://doi.org/10.5089/9781484322901.001.

Benczes István [2011]: Nemzeti szintű költségvetési szabályok használata az Európai Unióban. Külgazdaság, 55. évf. 3-4. sz. 55-75. o.

BenCzEs István [2013]: Kormányközi szerződéssel a költségvetési stabilitásért? Köz-gazdaság, 8. évf. 1. sz. 99-108. o.

BenCzes István [2014]: Európai költségvetési unió: tervek és kételyek. Köz-gazdaság, 9. évf. 2. sz. 67-84. o

Benczes István-VÁradi Szilvia [2011]: Aranyszabály helyett adósságfék - a német példa. Köz-gazdaság, 6. évf. 2. sz. 91-103. o.

Bergman, U. M.-Hutchison, M. M.-Jensen, S. H. E. [2013]: Do Sound Public Finances Require Fiscal Rules or Is Market Pressure Enough? European Commission, European Economy. Economic Papers, No. 489.

Bergman, U. M.-Hutchison, M. M.-Jensen, S. E. H. [2014]: Phoenix Rising From the Ashes: New Evidence on National Fiscal Rules in the EU. Conference paper. Swedish Network for European Studies in Economics and Business (SNEE) on European Integration, Mölle, http://web.econ.ku.dk/eprn_epru/Seminar/BHJ_fiscal\%20rules.pdf. 
Berndsen, R. [2001]: Postwar Fiscal Rules in the Netherlands: What Can We Learn for EMU? Fiscal Rules Conference, február 1. 367 o. https://doi.org/10.2139/ssrn.2094506.

Berta Dávid-Tóth G. Csaba [2017]: Költségvetési szabályok. Oktatási Füzetek, 14. sz. Magyar Nemzeti Bank, Budapest. https://www.mnb.hu/letoltes/mnb-oktatasi-fuzetek-14szam-digitalis.pdf.

Born, H. [1998]: The Behavior of U.S. Public Debt and Deficits. Quarterly Journal of Economics, Vol. 113. No. 3. 949-963. o. https://doi.org/10.1162/003355398555793.

Burnside, A. C. (szerk.) [2005]: Fiscal Sustainability in Theory and Practice: A Handbook. The World Bank Publications. Washington, D. C. https://doi.org/10.1596/978-0-8213-5874-0. Calmfors, L.-Wren-Lewis, S. [2011]: What should fiscal councils do? Economic Policy, Vol. 26. No. 68. 649-695. o. https://doi.org/10.1111/j.1468-0327.2011.00273.x.

Checherita-Westphal, C.-Ždarek, V. [2015]: Fiscal reaction function and fiscal fatigue: Evidence for the euro area. ECB Working Paper Series, 2036. https://www.ecb.europa.eu/ pub/pdf/scpwps/ecbwp2036.en.pdf.

Cordes, T.-Kinda, T.-Muthoora, P.-Weber, A. [2015]: Expenditure Rules: Effective Tools for Sound Fiscal Policy? IMF Working Paper, Vol. 15. No. 29. https://doi.org/10.5089/ 9781498390576.001.

Corsetti, G.-Roubini, N. [1991]: Fiscal deficits, public debt, and government solvency: Evidence from OECD countries. Journal of the Japanese and International Economies, Vol. 5. No. 4. 354-380. o. https://doi.org/10.1016/0889-1583(91)90004-a.

CotTARELli, C. [2011]: The risk octagon: A comprehensive framework for assessing sovereign risks. Presentation at the Sapienza University in Rome, január 25. http://www.imf.org/ external/np/fad/news/2011/docs/Cottarelli1.pdf.

Cottarelli, C.-Escolano, J. [2014]: Debt Dynamics and Fiscal Sustainability. PostCrisis Fiscal Policy. The MIT Press, Cambridge, 31-47. o. https://doi.org/10.7551/ mitpress/9780262027182.003.0003.

Croce, E.-Juan-Ramon, H. [2003]: Assessing Fiscal Sustainability: A Cross-Country Comparison. International Monetary Fund Working Paper, Vol. 3. No. 145. Washington, D. C. https://doi.org/10.5089/9781451856569.001.

Csaba LÁszló [1994]: Az összeomlás forgatókönyvei. Figyelő Kiadó, Budapest.

Csaba LÁszló [2002]: Az átalakulás fejlődéselmélete. Közgazdasági Szemle, 49. évf. 4. sz. 273-291. o.

Dahan, M.-Strawczynski, M. [2010]: Fiscal rules and composition bias in OECD countries. CESIFO Working Paper, No. 3088.

Darvas Zsolt-Kostyleva, V. [2011]: The fiscal and monetary institutions of CESEE countries. Bruegel Working Paper, No. 2.

Darvas Zsolt-Tschekassin, O. [2015]: Poor and under Pressure: The Social Impact of Europe's fiscal Consolidation. Bruegel Policy Contribution, No. 4.

De Cos, P. H.-Moral-Benito, E.-Koester, G. B.-Nickel, C. [2014]: Signaling fiscal stress in the euro area: A country-specific early warning system. ECB Working Paper, No. 1712. https://doi.org/10.2139/ssrn.2471464.

Debrun, X.-Kumar, M. [2007]: Fiscal Rules, Fiscal Councils and All That: Commitment Devices, Signaling Tools or Smokescreens? Proceedings of the 9th Banca d'Italia Workshop on Public Finance. Róma, Banca d'Italia. https://doi.org/10.2139/ssrn.2004371.

Debrun, X.-Moulin, L.-Turrini, A.-Ayuso-i-Casals, J.-Kumar, M. S.-Drazen, A.Fuest, C. [2008]: Tied to the mast? National fiscal rules in the European Union. Economic Policy, Vol. 23. No. 54. 298-362. o. https://doi.org/10.1111/j.1468-0327.2008.00199.x. 
EC [2006]: Numerical fiscal rules in the 25 EU Member States. Megjelent: Public finances in EMU. European Economy, No. 3. III. rész, 3. fejezet, 149-168. o. http://ec.europa.eu/economy_finance/ db_indicators/fiscal_governance/documents/1-a5_analysis_pfr_2006_ch3_en.pdf.

EC [2009]: Numerical fiscal rules in the EU Member States in 2008. Megjelent: Public finances in EMU. II. rész, 4. fejezet.

EC [2015]: Numerical fiscal rules in the EU Member States. European Commission, https:// ec.europa.eu/info/business-economy-euro/indicators-statistics/economic-databases/ fiscal-governance-eu-member-states/numerical-fiscal-rules-eu-member-countries en\#downloads.

Elbadawi, I.-Schmidt-Hebbel, K.-Soto, R. [2015]: Why do Countries have Fiscal Rules? Journal Economía Chilena, Vol. 18. No. 3. 28-61. o.

Hallerberg, M.-Strauch, R.-von Hagen, J. [2001]: The use and effectiveness of budgetary rules and norms in EU Member States. Report prepared for the Dutch Ministry of Finance by the Institute of European Integration Studies. Center for European Integration Studies, Bonn.

Hallett, A. H.-Von Hagen, J.-Lewis, J. [2003]: Fiscal Policy in Europe, 1991-2003: An Evidence-based Analysis. Centre for Economic Policy Research, London.

HAMKER, J. [2011]: Implementing Germany's new constitutional fiscal rules. Megjelent: Rules and Institutions for Sound Fiscal Policy after the Crisis. Papers presented at the Banca d'Italia workshop held in Perugia, március 31.-április 2.

Heinemann, F.-Yeter, M. [2014]: The effects of fiscal rules on public finances and their identification. Conference Paper. Evidenzbasierte Wirtschaftspolitik - Session: Fiscal Sustainability, No. B20-V1.

Heinemann, F.-Osterloh, S.-Kalb, A. [2013]: Sovereign risk premia: The link between fiscal rules and stability culture. ZEW Discussion Papers, No. 13-016. https://doi. org/10.2139/ssrn.2233388.

Heinemann, F.-Moessinger, M.-D.-Yeter, M. [2016]: Do fiscal rules constrain fiscal policy? A meta-regression-analysis. ZEW Discussion Paper, No. 16-027. https://doi. org/10.2139/ssrn.2762314.

Henning, C. R.-Kessler, M. [2012]: Fiscal federalism: US history for architects of Europe's fiscal union. Peterson Institute for International Economics, Working Paper, No. 1. https:// doi.org/10.2139/ssrn.1982709.

IMF [2009]: Fiscal Rules. Anchoring Expectations for Sustainable Public Finances. IMF Fiscal Affairs Department, Washington, D. C.

IMF [2012]: Fiscal Monitor. Balancing Fiscal Policy Risks. Fiscal Monitor, International Monetary Fund, Washington, D. C. http://www.imf.org/en/Publications/FM/Issues/2016/12/31/ Balancing-Fiscal-Policy-Risks.

IMF [2016]: The IMF and Europe. Factsheet, március 23. http://www.imf.org/external/np/ exr/facts/europe.htm.

JANKovics LÁszLó [2012]: Független költségvetési intézmények. Köz-Gazdaság, 7. évf. 1. sz. 147-164. o.

Kennedy, S.-Robisns, J. [2001]: The role of fiscal rules in determining fiscal performance. Department of Finance Canada, Working Paper, No. 16. http://www.fin.gc.ca/pub/pdfs/ wp2001-16e.pdf.

Kirchgässner, G. [2013]: Fiscal Institutions at the Cantonal Level in Switzerland. University of St. Gallen, Economics Working Paper Series, No. 1304. http://ux-tauri.unisg.ch/RePEc/ usg/econwp/EWP-1304.pdf. 
Kopits György [2001]: Fiscal Rules: Useful Policy Framework or Unnecessary Ornament. IMF Working Paper, No. 145. https://doi.org/10.2139/ssrn.2094462.

Kopits György [2011]: Independent Fiscal Institutions: Developing Good Practices. OECD Journal of Budgeting, Vol. 11. No. 3. 1-18. o. https://doi.org/10.1787/budget-11$5 \mathrm{~kg} 3 \mathrm{pdgcpn} 42$.

Kopits György-Romhányi Balázs [2010]: A Költségvetési Tanács indulásának tanulságai. Közgazdasági Szemle, 57. évf. 7. sz. 573-590. o.

Kopits, G.-Symansky, S. [1998]: Fiscal Policy Rules. IMF Occasional Paper, No. 162. IMF, Washington, https://doi.org/10.5089/9781557757043.084.

KoRNAI JÁNOs [2005]: Közép-Kelet-Európa nagy átalakulása - siker és csalódás. Közgazdasági Szemle, 52. évf. 12. sz. 907-936. o.

Locher, F. M.-Mischler, P.-Weber, W. [2015]: Intergovernmental co-ordination of fiscal policy in Switzerland. OECD Fiscal Federalism Studies Institutions of Intergovernmental Fiscal Relations Challenges Ahead: Challenges Ahead, 190-216. o. https:/doi. org/10.1787/9789264246966-12-en.

Luechinger, S.-Schaltegger, C. A. [2013]: Fiscal rules, budget deficits and budget projections. International Tax and Public Finance, Vol. 20. No. 5. 785-807. o. https://doi. org/10.1007/s10797-012-9245-9.

Mahmood, T.-Rauf, S. A. [2012]: Public debt sustainability. Evidence from Developing Country. Pakistan Economic and Social Review, Vol. 50. No. 1. 23-40. o.

Marneffe, W.-Van Aarle, B.-Van der Wielen, W.-Vereeck, L. [2010]: The Impact of Fiscal Rules on Public Finances: Theory and Empirical Evidence for the Euro Area. CESifo Working Paper Series, No. 3303.

MELLÁR TAMÁs [2016]: Szolgálólányból királycsináló - avagy az ökonometria makroökonómiai térhódítása? Közgazdasági Szemle, 63. évf. 3. sz. 285-306. o. https://doi.org/10.18414/ ksz.2016.3.285.

Muraközy LÁszló [2012]: Államok kora. Az európai modell. Akadémiai Kiadó, Budapest. Musgrave, R. A. [1959]: The Theory of Public Finance. McGraw-Hill, New York.

Nerlich, C.-Reuter, W. H. [2013]: The design of national fiscal frameworks and their budgetary impact. ECB Working Paper, No. 1588.

Nickell, S. [1981]: Biases in Dynamic Models with Fixed Effects. Econometrica, Vol. 49. No. 6. 1417-1426. o. https://doi.org/10.2307/1911408.

OECD [1991]: Economic outlook 49. Head of Publications Service, OECD, Párizs.

PÁpa Levente-Valentiny i Ákos [2008]: Költségvetési fenntarthatóság. Közgazdasági Szemle, 55. évf. 5. sz. 395-426. o.

Poterba, J. M. [1996]: Budget Institutions and Fiscal Policy in the U.S. States. American Economic Review, Vol. 86. No. 2. 395-400. o.

Reinhart, C. M.-Rogoff, K. [2009]: This Time is Different: Eight Centuries of Financial Folly. Princeton University Press, Princeton and Oxford, https://doi.org/10.2189/ asqu.2010.55.3.522.

Reuter, W. H. [2015]: National numerical fiscal rules: Not complied with, but still effective? European Journal of Political Economy, Vol. 39. 67-81. o. https://doi.org/10.1016/j. ejpoleco.2015.04.002.

Roaf, J.-Atoyan, R.-Joshi, B.-Krogulski, K. [2014]: 25 Years of Transition Post-Communist Europe and the IMF. Regional Economic Issues. Special Report. International Monetary Fund, Washington, D. C. http://www.imf.org/external/region/bal/rr/2014/25_years_of_ transition.pdf. 
SACChi, A.-Salotti, S. [2015]: The impact of national fiscal rules on the stabilisation function of fiscal policy. European Journal of Political Economy, Vol. 37 No. C. 1-20. o. https://doi.org/10.1016/j.ejpoleco.2014.10.003.

Tóтн G. Csaвa [2010]: Állami keresletélénkítés és automatikus stabilizátorok. Pénzügyi Szemle, 55. évf. 1. sz. 51-68. o.

Tóтн G. Csaba [2017]: Deficithajlam és a költségvetési szabályok. Köz-gazdaság, 12. évf. 3. sz. 149-163. о.

US GAO [1994]: Deficit reduction. Experiences of Other Nations. United States General Accounting Office, Washington, D. C. 20548.

VIDOvics-DAnCs ÁGNes [2014]: Államcsődök - az államcsőd költségei régen és ma. Közgazdasági Szemle. 61. évf. 3. sz. 262-278. o.

World BAnk [2008]: Montenegro, Beyond the Peak: Growth Policies and Fiscal Constraints. Report, No. 46660.

\section{Függelék}

F1. táblázat

Az alindexek tartalma és a vizsgált szabályok eloszlása a kapott érték alapján

Értékelési szempontok

A1: JOGI HÁTtÉR (1: politikai nyilatkozat, 2: koalíciós megállapodás, 3: törvény 4: alkotmány)

A2: CÉLOK RÖGZÍTÉSE (1: a célok szabadon megváltoztathatók, 2: a célok korlátozottan megváltoztathatók, 3: a célokon nem lehet változtatni)

A3: ELLENŐRZŐ TESTÜLET (1: nincs ilyen szervezet, 2: kormányhoz kapcsolódó szervezet 3: kormánytól független szervezet)

A4: RIASZTÁsi MECHANIZMUS (0: nincs, 1 : van)

A5: SZANKCIONÁLÓ TESTÜLET (1: nincs ilyen szervezet, 2: kormányhoz kapcsolódó szervezet, 3: kormánytól független szervezet)

A6: KORREKCIÓs MECHANIZMUS (1: nincs, 2: a kormány feladata korrigálni, 3: van automatikus korrekciós mechanizmus lehetséges szankciókkal, 4: van automatikus korrekciós mechanizmus automatikus szankciókkal)

A7: MENTESÍTŐ ZÁRADÉK (0: nincs, 1 : van)

A8: NYILVÁNOSSÁG (1: a szabály nem jelenik meg a médiában, 2: a szabály megjelenik a médiában, de a nemteljesítés nem generál közéleti vitákat, 3: a nemteljesítés közéleti vitákat generál a médiában) 


\section{F1. ábra}

A megfigyelések csoportosítása annak függvényében, hogy örökölt vagy saját szabályrendszer volt-e érvényben
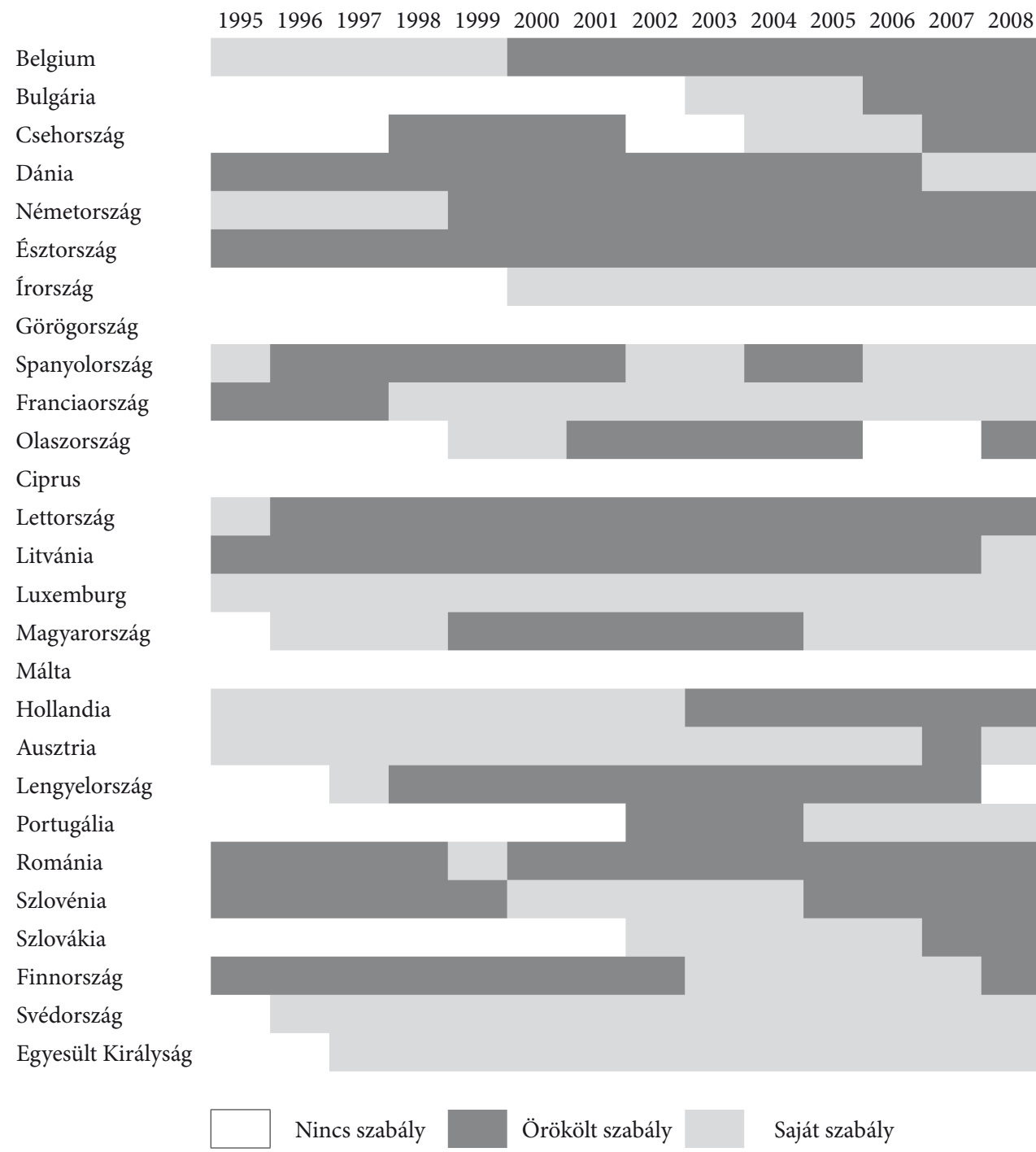

Forrás: saját gyüjtés. 
F2. táblázat

$\mathrm{Az}$ (1) egyenletben szereplő regressziós becslés $G A P 2$ változós eredményei

[A GAP3 helyett GAP2 kétértékű változó szerepel az (1) egyenletben, amely 1, ha a kibocsátási rés pozitív, ellenkező esetben 0]

\begin{tabular}{lc}
\hline Magyarázó változók & Függő változó $(p b)$ \\
\hline Elsődleges egyenleg $(p b[-1])$ & $0,16^{* *}$ \\
Fiscal Rules Index $(F R I)$ & $(0,02)$ \\
FRI $\times$ GAP2 & $(0,65$ \\
& $0,95^{* * *}$ \\
Kibocsátási rés $(G A P 2)$ & $(0,00)$ \\
& $0,44^{* *}$ \\
Kormányzati hatékonyság $(W G I)$ & $(0,05)$ \\
Adósságráta, késleltetéssel $(d[-1])$ & 1,83 \\
Választói ciklusok $(E L C T)$ & $(0,11)$ \\
Bruttó hazai termék $(G D P)$ & 0,03 \\
Euró bevezetése $(E U R O)$ & $(0,23)$ \\
$N$ & 0,11 \\
$R^{2}$ & $(0,19)$ \\
\hline
\end{tabular}

Megjegyzés: zárójelben a $p$ valószínüségi értékek szerepelnek. Az Arellano-Bond-becslést klaszterezett standard hibákkal végeztük el ország és idő fix hatás mellett.

${ }^{* * *} 1$ százalékos szinten, ${ }^{* *} 5$ százalékos szinten, ${ }^{*} 10$ százalékos szinten szignifikáns értékek. 
F3. táblázat

Az (1) egyenletben szereplő regressziós becslés a GDP-arányos ciklikusan kiigazított elsődleges egyenleg szerepeltetésével

Magyarázó változók

Függő változó $(c a p b)$

Ciklikusan kiigazított elsődleges egyenleg, késleltetéssel (capb[-1])

$0,25^{\star * *}$

Fiscal Rules Index (FRI)

$-1,03$

$(0,15)$

$F R I \times G A P 3$

$0,96^{* * *}$

$(0,01)$

Kibocsátási rés (GAP3) $-0,36$

$(0,17)$

Kormányzati hatákonyság (WGI) $-0,98$

Adósságráta, késleltetéssel $(d[-1])$

Választási ciklus (ELCT)

0,14

$(0,13)$

Bruttó hazai termék (GDP)

0,02

$(0,95)$

Euró bevezetése (EURO)

1,26

$(0,28)$

$N$

Megjegyzés: zárójelben a $p$ valószínűségi értékek szerepelnek. Az Arellano-Bond-becslést klaszterezett standard hibákkal végeztük el ország és idő fix hatás mellett.

${ }^{* * *} 1$ százalékos szinten, ${ }^{\star *} 5$ százalékos szinten, ${ }^{*} 10$ százalékos szinten szignifikáns értékek. 